
Aging, U.S. Senate

June 2017

\title{
OLDER WORKERS
}

Phased Retirement Programs, Although Uncommon, Provide Flexibility for Workers and Employers 


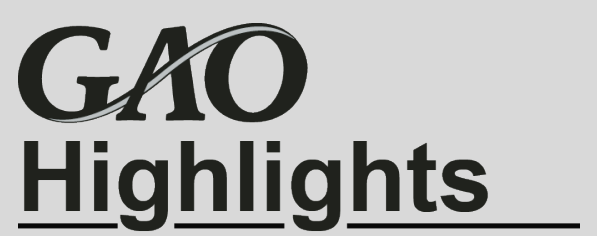

Highlights of GAO-17-536, a report to the Special Committee on Aging, U.S. Senate

\section{Why GAO Did This Study}

As the large baby boomer generation retires, the workforce will lose much of their knowledge and experience. Encouraging phased retirement, in which older workers reduce their work hours with their currentemployer to transition into retirement, has been cited by retirement experts as one way to mitigate this loss. GAO was asked to review the work patterns of older Americans and phased retirement programs.

In this report, GAO examines (1) recent trends in the labor force participation of older workers, (2) the extent to which employers have adopted phased retirement programs and what type of employers offer them, and (3) what challenges and benefits, if any, exist in designing and operating phased retirement programs.

GAO analyzed data from two nationally representative surveys, the Health and Retirement Study(2004-2014) and the Current Population Survey (20052016); reviewed relevant federal laws and regulations; conducted a literature review; and interviewed 16 experts on retirement and 9 employers who offer or considered offering phased retirement programs. While phased retirement programs exist in both the private sector and government, this report focuses on private sector programs.

\section{What GAO Recommends} $\mathrm{GAO}$ is not making recommendations in this report.

View GAO-17-536. For more information, contact Charles Jeszeck at (202) 512-7215 or jeszeckc@gao.gov.

\section{Phased Retirement Programs, Although Uncommon, Provide Flexibility for Workers and Employers}

\section{What GAO Found}

Participation of older workers in the labor market has increased in the last decade, according to GAO analysis. Further, most individuals ages 61 to 66 who were still working maintained a full-time work schedule. However, although about a quarter of workers in this age group had planned to reduce hours as they transitioned to retirement, fewer than 15 percent subsequently reported being partly retired or gradually retiring from their career jobs.

While no nationally representative data on the prevalence of phased retirement exist, GAO's review of studies and interviews with retirement experts indicate that formal phased retirement programs are relatively uncommon. Of those that are offered, they are more common among employers with larger or technical and professional workforces, such as education, consulting, and high-tech, according to studies GAO reviewed (see table). Nine of 16 experts GAO interviewed explained that industries with skilled workers or with labor shortages are motivated to offer phased retirement because their workers are hard to replace.

Estimated Percentage of Society for Human Resource Management Members with Formal Phased Retirement Programs, by Industry

\begin{tabular}{lr}
\hline Industry & Estimated Percentage Within Select Industry \\
\hline Education & $12 \%$ \\
\hline Utilities & $10 \%$ \\
\hline Consulting & $7 \%$ \\
\hline High Tech & $7 \%$ \\
\hline All Industries & $5 \%$ \\
\hline
\end{tabular}

Source: Society for Human Resource Management 2016 survey data | GAO-17-536

Formal phased retirement programs present design and operational challenges for employers, including compliance with provisions and laws related to discrimination, according to publications GAO reviewed and experts and employers GAO interviewed. For example, in one study GAO reviewed, 71 percent of large employers agreed that regulatory complexities and ambiguities involving federal tax and age discrimination laws impact their ability to offer phased retirement programs. Experts and employers said programs that target highly skilled workers, who are often highly paid, could violate rules that allow for favorable tax treatment that generally prohibit qualified pension plans from favoring highly compensated employees. Despite these challenges, most employers GAO interviewed who reported having phased retirement programs found them beneficial. For example, eight of the nine employers GAO interviewed said they were able to address various design and operational challenges and cited program benefits related to worker retention, knowledge transfer, transition into retirement, and workforce planning. 


\section{Contents}

Letter

Background

More Older Workers Are Extending Their Labor Force

Participation, and More Plan to Gradually Reduce Work Hours

Than Actually Do

Formal Phased Retirement Programs Are Not Common, with

Larger Employers and Those with Technical and Professional

Workforces More Likely to Offer Them

Designing Phased Retirement Programs Can Be Challenging,

According to Experts, Employers, and Publications, but Some

Employers Report Benefits in Doing So

Agency Comments

Appendix I

Objectives, Scope, and Methodology

38

Appendix II

Profiles of Phased Retirement Programs for Selected Employers

Appendix III

GAO Contact and Staff Acknowledgments

Related GAO Products

Tables

Table 1: Older Workers by Occupational Sector, 2016

Table 2: Estimated Percentage of Society for Human Resource Management Members Offering Formal Phased Retirement Programs, by Selected Industry, 2016

Figures

Figure 1: Estimated Labor Force Participation for Older Men and Women, 2005-2016

Figure 2: Percentage of Early Baby Boomers answering "Yes" to 'Could you reduce the hours in your work schedule?' 
Figure 3: Selected Retirement Employment Strategies of Early Baby Boomers Still Working At Time of Survey, 20042014

Figure 4: Percentage of Early Baby Boomers Who Would Like to Reduce Hours Even If Earnings Reduced Proportionally, 2004-2014

Figure 5: Ability, Interest, and Realization of Reduced Working

Hours among 61- to 66-Year-Olds, 2014

\section{Abbreviations}

$\begin{array}{ll}\text { ADA } & \text { Americans with Disabilities Act of } 1990 \\ \text { ADEA } & \text { Age Discrimination in Employment Act of } 1967 \\ \text { ASEC } & \text { Annual Social and Economic Supplement } \\ \text { BLS } & \text { Bureau of Labor Statistics } \\ \text { BRR } & \text { Balanced Repeated Replication } \\ \text { CPS } & \text { Current Population Survey } \\ \text { DB } & \text { defined benefit } \\ \text { DC } & \text { defined contribution } \\ \text { DOL } & \text { Department of Labor } \\ \text { EEOC } & \text { Equal Employment Opportunity Commission } \\ \text { ERISA } & \text { Employee Retirement Income Security Act of 1974 } \\ \text { HRS } & \text { Health and Retirement Study } \\ \text { IRA } & \text { individual retirement account } \\ \text { IRC } & \text { Internal Revenue Code } \\ \text { IRS } & \text { Internal Revenue Service } \\ \text { OPM } & \text { Office of Personnel Management } \\ \text { SHRM } & \text { Society for Human Resource Management } \\ \text { Treasury } & \text { Department of the Treasury }\end{array}$

This is a work of the U.S. government and is not subject to copyright protection in the United States. The published product may be reproduced and distributed in its entirety without further permission from GAO. However, because this work may contain copyrighted images or other material, permission from the copyright holder may be necessary if you wish to reproduce this material separately. 
June 20, 2017

The Honorable Susan Collins

Chairman

The Honorable Robert Casey

Ranking Member

Special Committee on Aging

United States Senate

The retirement of the large baby boomer generation will lead to the workforce losing much of its knowledge and experience. Further, as GAO has previously reported, most households approaching retirement have low retirement savings, generating concern about older Americans' preparedness for retirement. ${ }^{1}$ These effects could be mitigated, to some extent, if Americans were encouraged to continue to work at older ages. ${ }^{2}$ According to retirement experts, one option available to accomplish this is phased retirement. Phased retirement is when workers reduce their working hours with their current employer in order to transition into retirement.

GAO was asked to review the work patterns of older Americans and examine phased retirement programs. In this report, we examine (1) recent trends in the labor force participation of older workers, (2) the extent to which employers have adopted phased retirement programs and what type of employers offer them, and (3) what challenges and benefits, if any, exist to the design and operation of phased retirement programs.

To describe the recent trends in labor force participation of older workers, we analyzed nationally representative data from 2005 to 2016 in the Current Population Survey (CPS) and the 2004-2014 Health and Retirement Study (HRS), two datasets with information about the labor force participation of older workers. We examined the reliability of these data by reviewing documentation and conducting selected data checks and found it sufficiently reliable for our purposes. To inform all sections of this report, we reviewed relevant federal laws and regulations and

\footnotetext{
${ }^{1} \mathrm{GAO}$, Retirement Security: Most Households Approaching Retirement Have Low Savings, GAO-15-419 (Washington, D.C.: May 12, 2015).

2 GAO, Older Workers: Demographic Trends Pose Challenges for Employers and Workers, GAO-02-85 (Washington, D.C.: Nov. 16, 2001).
} 
conducted a literature review that included academic studies and industry surveys and reports as well as relevant articles. We also interviewed agency officials and 16 experts, such as consultants, representatives of industry and interest groups, and academics. We identified these experts through our review of relevant literature and through expert referral. Finally, we conducted semi-structured interviews with nine employers who offer or considered offering phased retirement programs. We selected these employers to represent a variety of employer types by location, size, and industry. Although the information from these interviews is not generalizable, the examples and perspectives provided were useful in describing the issues related to phased retirement. While there are phased retirement programs in both the private sector and government, this report focuses on private sector programs. ${ }^{3}$

We conducted this performance audit from April 2016 to June 2017 in accordance with generally accepted government auditing standards. Those standards require that we plan and perform the audit to obtain sufficient, appropriate evidence to provide a reasonable basis for our findings and conclusions based on our audit objectives. We believe that the evidence we obtained provides a reasonable basis for our findings and conclusions based on our audit objectives. For more information on our objectives, scope, and methodology, see appendix I. workers can reduce their working hours in order to transition into retirement. ${ }^{4}$ Phased retirement may include partial drawdown of defined contribution or defined benefit pension benefits and a knowledge-transfer component. Depending on the employer, the program may include health

\footnotetext{
3 In 2014, the Office of Personnel Management (OPM) issued regulations on implementation of the agency-level federal phased retirement programs. These regulations provide guidance to agencies and employees about eligibility, benefits, and annuity calculation. Individual agencies have discretion to determine, for example, the criteria used to approve requests to enter the program and positions or geographic locations that may be included or excluded. OPM processes agencies' phased retirement applications and provides guidance on administering the programs. Beginning in 2015, some federal agencies began implementing phased retirement programs. As other agencies are still implementing their programs, it is too early to assess the federal program's overall effect.

${ }^{4} \mathrm{GAO}$ selected this definition of formal phased retirement programs on the basis of review of relevant literature. Many workers not participating in a phased retirement program would likely either continue working full time or retire completely.
} 
coverage for participants. ${ }^{5}$ In contrast to formal programs, informal phased retirement arrangements are not part of a formal program but are alternate methods to ease into retirement with the same employer, such as an ad hoc agreement or retirement followed by a term as a contractor. ${ }^{6}$

Employer goals for formal phased retirement programs vary, but may include knowledge retention, skills transfer, workforce planning, and retirement planning. Employers can use phased retirement as a human resource tool not only to retain workers with essential skills or knowledge, but also to provide an incentive for other workers to retire. Additionally, workers may find phased retirement to be a positive way to ease into retirement.

Sources of Retirement Income
Income in retirement can come from multiple sources, including but not limited to: (1) Social Security, (2) payments from defined benefit (DB) plans, and (3) retirement savings, such as savings in an individual retirement account (IRA) or a defined contribution (DC) plan, such as a 401(k).

Social Security: Social Security retirement benefits partially replace earnings lost due to retirement and provide a base of income upon which to build. The initial monthly benefit amount depends on the worker's earnings history and the age at which he or she chooses to begin receiving benefits, as well as other factors. Social Security pays unreduced benefits at the full retirement age, which has gradually increased from 65 (for 1937 and earlier birth cohorts) to 67 (for 1960 and later birth cohorts). Workers can elect to receive retirement benefits as early as age 62 , but the benefit amount is reduced compared to benefits at full retirement age. Workers who retire after their full retirement age

\footnotetext{
${ }^{5}$ For example, some formal phased retirement programs subsidize health care for workers or adjust pension benefits. See appendix II.

${ }^{6}$ For purposes of this report, GAO selected this definition of informal phased retirement arrangements based on our review of relevant literature. Neither formal phased retirement programs nor informal phased retirement arrangements include situations in which a worker changes jobs or employers.
} 
receive a benefit increase for each month they delay claiming retirement benefits, up to age $70 .^{7}$

A worker may also choose to work and receive Social Security benefits. However, depending on his or her earnings, those benefits may be reduced until full retirement age, although any earnings in and after the month a worker reaches full retirement age will not reduce retirement benefits. ${ }^{8}$ Additionally, for workers who have income above a certain threshold, their Social Security benefits may be taxed. ${ }^{9}$

Social Security faces significant financial challenges, as we have previously reported. ${ }^{10}$ According to the 2016 report from the Social Security Board of Trustees, the Old-Age and Survivors Insurance trust fund (from which Social Security retirement and survivors' benefits are paid) is projected to be able to pay full benefits until $2035 .{ }^{11}$ The report warns that unless action is taken to avert depletion of the trust fund, continuing revenue is projected to be sufficient to cover about 75 percent

\footnotetext{
${ }^{7}$ Retirees born in 1943 or later receive an 8 percent increase for each full year and a prorated increase for each partial year they delay claiming, until age 70 , after which no further increases are granted. For example, with a full retirement age of 66, an individual who begins claiming benefits in 2017 at age 70 would receive benefits increased by 32 percent.

8 In 2017, the Social Security Administration withholds $\$ 1$ of benefits for every $\$ 2$ of earnings above $\$ 16,920$ for someone younger than the full retirement age for the full year. In the year the claimant reaches full retirement age, the earnings threshold rises to $\$ 44,880$ (for 2017), and $\$ 1$ of benefits is withheld for every $\$ 3$ in earnings above that threshold in the months prior to the claimant reaching full retirement age. The Social Security Administration also applies a separate monthly earnings limit for one year after claiming. According to DOL officials, this does not represent an overall reduction in lifetime benefits in general. Benefits are reduced while the person is working prior to full retirement age, but benefits are increased after full retirement age.

${ }^{9}$ For example, individual income tax filers may pay tax on up to 50 percent of their benefits if their income (defined as the sum of adjusted gross income, certain tax-exempt interest income, and half of their Social Security benefits) is $\$ 25,000$ or over $(\$ 32,000$ or over for a married couple filing jointly). In addition, because of changes in 1993, some individual filers may pay tax on up to 85 percent of their benefits if their income exceeds $\$ 34,000$ ( $\$ 44,000$ for a married couple).

${ }^{10} \mathrm{GAO}$, Social Security's Future: Answers to Key Questions, GAO-16-75SP (Washington, D.C.: October 2015).

11 The 2016 Annual Report of the Board of Trustees of the Federal Old-Age and Survivors Insurance and Federal Disability Insurance Trust Funds. U.S. Government Publishing Office (Washington, D.C.: June 22, 2016).
} 
of scheduled benefits at that time. This projection raises the possibility of changes to Social Security benefits, taxation, or both before 2035.

Defined Benefit Plans: DB plans offer pension benefits in the form of an annuity that provides a periodic payment for life, typically on a monthly basis, and may offer a lump-sum distribution option. They are employment-based and offer benefits determined by a formula that includes factors specified by the plan, such as salary and years of service. Specifics on how the calculation takes those factors into account can affect the final benefit amount. For example, this amount may be determined by the average of the worker's last 5 years of wages, or the average of the worker's highest 5 years of wages. Workers may be able to receive in-service distributions from their DB plan (i.e., draw a pension benefit while they are still working), generally no earlier than age 62 .

Over the past several decades, private sector employers have shifted from providing a large share of retirement benefits through DB plans to relying much more heavily on DC plans, according to Department of Labor data. ${ }^{12}$ In 1975, there were about 103,346 DB plans and 207,748 DC plans. By 2014, the number of DB plans had shrunk by more than half (to 44,869 ) while the number of DC plans had more than tripled (to $640,334)$.

Retirement Savings: Two primary types of retirement savings vehicles are IRAs and employer-sponsored DC plans (such as 401(k) and 403(b) plans). ${ }^{13}$ For both DC plans and IRAs, benefits accrue in the form of account balances, which grow from contributions made by workers (and sometimes by their employers) and investment returns. DC plans and IRAs often place the primary responsibility on individuals to participate in, contribute to, and manage their accounts throughout their working careers and to manage their savings throughout retirement. Workers and employers who contribute to retirement savings accounts generally receive favorable federal tax treatment, such as tax deductions or exclusions for contributions and tax-deferred or tax-free returns on

\footnotetext{
12 U.S. Department of Labor, Employee Benefits Security Administration, "Private Pension Plan Bulletin Historical Tables and Graphs: 1975-2014" (September 2016). Data is from Form 5500 filings and excludes "one-participant plans."

${ }^{13}$ For 2017 , individuals can contribute up to $\$ 5,500$ in IRAs $(\$ 6,500$ for those age 50 or older), while the contribution limit for $401(\mathrm{k})$ plans is $\$ 18,000$ ( $\$ 24,000$ for those age 50 or older).
} 
investment. ${ }^{14} \mathrm{~A}$ worker may start to withdraw, without a penalty, from these types of retirement savings vehicles as early as age $591 / 2$, if the DC plan or IRA allows it.

In prior work, we analyzed data from the 2013 Survey of Consumer Finances and found that about half of households age 55 and older had no retirement savings, such as in a $401(\mathrm{k})$ or an IRA. ${ }^{15}$ Moreover, we also found that many older households without retirement savings had few other resources, such as a DB plan or nonretirement savings, to draw on in retirement. Social Security remains the largest component of household income in retirement, making up an average of 52 percent of household income for those ages 65 and older.

Federal Oversight of Laws
and Regulations Related
to Phased Retirement

Federal Oversight of Laws to Phased Retirement
The Internal Revenue Service (IRS) within the Department of the Treasury (Treasury), the Department of Labor (DOL), and the Equal Employment Opportunity Commission (EEOC), as part of their work, have the primary responsibility for administering the laws and regulations that affect employment programs for older workers such as phased retirement.

The Employee Retirement Income Security Act of 1974 (ERISA) is the primary federal law governing the sponsoring of pension plans in the private sector. Under ERISA, both IRS and DOL have important authorities and responsibilities.

IRS: IRS determines whether private sector pension plans qualify for preferential tax treatment under the Internal Revenue Code. In determining the qualification of a plan, IRS enforces Internal Revenue Code nondiscrimination requirements, which prohibit a qualified pension plan from discriminating in favor of highly compensated employees (in comparison to lower paid, rank and file employees). These nondiscrimination requirements would apply to qualified plans, including

\footnotetext{
${ }^{14}$ Generally, contributions to 401 (k) plans and traditional IRAs are not subject to income tax when made (26 U.S.C. §§ 402(e)(3) and 219(a) and (e), respectively); and distributions or withdrawals of principal or earnings from them are subject to income tax (26 U.S.C. $\S \S 402(a)$ and 408(c)(1), respectively). Contributions to Roth IRAs are not taxdeductible, but after one has been established for 5 years, upon reaching age $591 / 2$, an individual may make withdrawals of principal or earnings not subject to income tax. 26 U.S.C. $\S 408 \mathrm{~A}(\mathrm{c})$ and (d).

${ }^{15}$ GAO-15-419.
} 
those maintained by employers that offer phased retirement. Specifically, qualified plans must show that they do not discriminate in two ways: 1) by demonstrating they do not favor highly compensated employees in terms of plan coverage, and 2) they are not providing disproportionate contributions or benefits to those highly compensated employees.

DOL: Under ERISA, DOL is responsible for protecting the interests of plan participants. DOL's Employee Benefits Security Administration takes primary responsibility for enforcing ERISA reporting and disclosure requirements, such as informing participants and sponsors of their rights and obligations under the plan. The Employee Benefits Security Administration also enforces ERISA's fiduciary requirements, i.e., the standards of conduct for those who exercise discretionary authority or manage a plan or have authority to dispose of its assets. ${ }^{16}$

Under ERISA, the ERISA Advisory Council was established to advise the Secretary of Labor with respect to carrying out his/her duties under the act. The Council established a Working Group on Phased Retirement to, among other things, examine issues facing employers who wish to create phased retirement programs and the various legal and regulatory obstacles to implementing phased retirement.

EEOC: As part of its responsibility, the EEOC enforces the Age Discrimination in Employment Act of 1967 (ADEA) and Titles I and V of the Americans with Disabilities Act of 1990 (ADA). The ADEA provides protection for workers ages 40 and older from employment discrimination because of age. The ADEA applies to all the terms, conditions, or privileges of employment, including hiring, firing, promotion, lay-off, compensation, benefits, job assignments, and training. The ADA provides, among other things, for protections from employment discrimination due to disability and reasonable accommodation for qualified workers.

\footnotetext{
${ }^{16}$ DOL may intervene in any matters that materially affect the rights of participants. See Department of Labor, Employee Benefits Security Administration, History of EBSA and ERISA, accessible at www.dol.gov/ebsa/aboutebsa/history.html.
} 


\section{Population Aging and Economic Productivity}

While not all researchers agree, it has been suggested by some that as the population ages and the number of baby boomers leaving the labor force increases, there could be a loss of economic productivity. ${ }^{17}$ This potentially has important implications for future economic growth. In a 2016 study, researchers found that a 10 percent increase in the percentage of the population age 60 and older decreases the growth rate of gross domestic product (GDP) per capita by 5.5 percent. ${ }^{18}$ According to this study, two-thirds of the reduction is due to slower growth in the labor productivity of workers across the age distribution, while one-third arises from slower labor force growth. The researchers say their results imply that annual GDP growth will slow by 1.2 percentage points this decade. The availability of phased retirement, by extending labor force participation, has the potential to provide options that would be beneficial both to the older workers and the overall economy.

\footnotetext{
17 See, for example, Rudolph G. Penner, Pamela Perun, and Eugene Steuerle, Legal and Institutional Impediments to Partial Retirement and Part-Time Work by Older Workers, The Urban Institute (November 2002), and Kevin L. Kliesen, As Boomers Slow Down, So Might the Economy, The Regional Economist, Federal Reserve Bank of St. Louis (July 2007). For an alternate perspective, see Ronald Lee, Macroeconomics, Aging and Growth, National Bureau of Economic Research (Cambridge, MA: June 2016).

${ }^{18}$ Nicole Maestas, Kathleen J. Mullen, and David Powell, The Effect of Population Aging on Economic Growth, the Labor Force and Productivity, NBER Working Paper No. 22452 (July 2016).
} 
More Older Workers Are Extending Their Labor Force Participation, and More Plan to Gradually Reduce Work Hours Than Actually Do

Older Workers' Labor
Force Participation Has
Increased Overall in the
Last Decade, Particularly
for Those Over Age 65

Older Workers' Labor Force Participation Has Last Decade, Particularly for Those Over Age 65
In 2005, GAO reported that labor force participation rates of older workers were projected to rise between 2005 and 2015 and this has indeed been the case. ${ }^{19}$ This increase in labor force participation among older workers occurred at the same time that the workforce participation of the U.S. population overall declined by approximately 3 percentage points (see fig. 1). The Bureau of Labor Statistics (BLS) and GAO reports anticipated this trend among older workers prior to the recession of 2007-2009, and the negative effect of the recession on the income security of older workers may have added an incentive for older workers to keep working. ${ }^{20}$ Increases in labor force participation by women ages 55 to 64 and by women and men age 65 and older were the primary contributors to the overall increased labor force participation among older workers. Men ages 55 to 64 kept their labor force participation relatively stable from 2005 to 2016.

BLS reports that it expects the labor force participation of those age 65 and older will continue to increase and that older workers will constitute a larger part of the workforce overall by 2024 as the population in general

\footnotetext{
19 GAO, Older Workers: Labor Can Help Employers and Employees Plan Better for the Future, GAO-06-80 (Washington, D.C.: Dec. 5, 2005). GAO generally defines older workers as those age 55 and older.

${ }^{20} \mathrm{GAO}$ previously reported that the labor force participation of older workers continued to increase during the recession, though an increasing proportion of older part-time workers would have preferred full-time work. The recession left older adults with difficult choices, such as reconsidering when to retire given the decline in stocks and housing prices. Further, during the recession, older workers who had lost their jobs in the last 3 years had more difficulty returning to work and the median duration of unemployment rose. See GAO, Income Security: Older Adults and the 2007-2009 Recession, GAO 12-76 (Washington, D.C.: Oct. 17, 2011).
} 
ages. ${ }^{21}$ However, BLS expects the overall labor force participation rate for those 55 and older to decline as the baby boom generation moves from pre-65 to the over 65 category. According to the BLS report, this is primarily because the baby boomers make up a disproportionately large share of the labor force and as they move into age groups with lower participation rates, this will lower the average labor force participation both overall and for the 55 and older population.

Figure 1: Estimated Labor Force Participation for Older Men and Women, 2005-2016

Labor force participation, age 55-64 and all ages

80

70

60

50

40

30

20

10

0

200520062007200820092010201120122013201420152016

Year

Men, age 55-64

-ב-- Men and women, all ages

Women, age 55-64
Labor force participation, age 65 and older

30

25

20

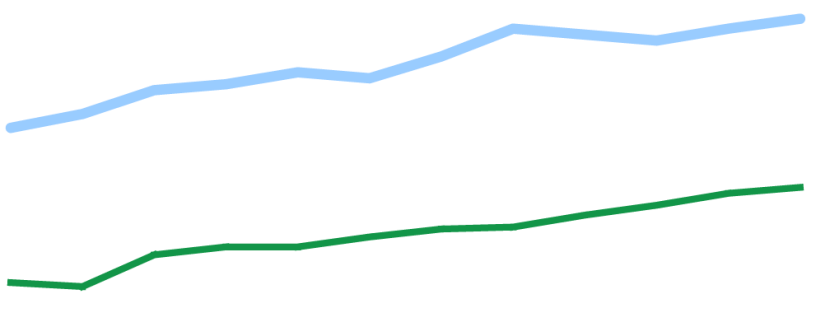

10

5

0 200520062007200820092010201120122013201420152016 Year

Men, age 65 and older

Women, age 65 and older

Source: GAO analysis of Current Population Survey-Annual Social and Economic (ASEC) Supplement, 2005-2015. | GAO-17-536

Note: Estimates used to generate this graphic are statistically significant at the $p<.05$ level or better and the $95 \%$ confidence interval is approximately $+/-1.5$ percentage points or less for all estimates.

Overall, in 2016, about 40 percent of all individuals age 55 and over participated in the labor force, and unemployment was lower than for the population as a whole (monthly unemployment ranged from 3.3-3.9

${ }^{21}$ Mitra Toossi, "Labor force projections to 2024: the labor force is growing, but slowly." Monthly Labor Review, Bureau of Labor Statistics, December 2015.

http://www.bls.gov/opub/mlr/2015/article/labor-force-projections-to-2024.htm 
percent for older workers in 2016, as compared to 4.7-5.0 percent for all ages). ${ }^{22}$ According to GAO analysis of CPS data, most workers age 55 and over work full-time.

Analysis of CPS data suggests that older workers are more concentrated in white-collar and service occupations. According to three of 16 experts we interviewed, white-collar workers are likely to work longer, partly because their jobs tend to be less physically demanding than blue-collar jobs. Table 1 provides a summary of the percentage of older workers by occupational sector.

Table 1: Older Workers by Occupational Sector, 2016

\begin{tabular}{lrr}
\hline & $\begin{array}{r}\text { Percentage of Workers } \\
\text { Ages 55-64 in the Sector }\end{array}$ & $\begin{array}{r}\text { Percentage of Workers } \\
\text { Ages 65-74 in the Sector }\end{array}$ \\
\hline White-collar $^{a}$ & $65 \%$ & $69 \%$ \\
\hline Service $^{b}$ & $14 \%$ & $15 \%$ \\
\hline Blue-collar $^{c}$ & $21 \%$ & $16 \%$ \\
\hline Total & $\mathbf{1 0 0 \%}$ & $\mathbf{1 0 0 \%}$ \\
\hline
\end{tabular}

Source: GAO analysis of the Current Population Survey (CPS) Annual Social and Economic (ASEC) Supplement, 2016 | GAO-17-536 Note: The columns do not sum to 100 due to rounding error. Estimates used to generate this graphic are statistically significant at the $p<.05$ level or better and the $95 \%$ confidence interval is approximately +/- 2 percentage point for all estimates.

${ }^{a}$ White-collar occupations were defined as executive, administrator, manager, sales, administrative support, professional, and technical.

${ }^{\mathrm{b}}$ Services were separated from blue-collar and white-collar occupations since there was a significant amount of overlap between these two categories within the service category. Services occupations were defined as private household, protective services, food preparation, health services, cleaning and building services, and personal services.

'Blue-collar occupations were defined as production, craft, repair, farming, forestry, fishing, transportation, machine operator and assembler, laborers and handlers.

22 GAO previously reported that while older workers generally have lower unemployment rates overall, once they do become unemployed, it takes longer to find reemployment, they have a greater duration of unemployment, and they may end up working for lower wages or part time when they actually want a full time job. This can cause them to draw down retirement savings or claim Social Security benefits before they reach their full retirement age. See GAO, Unemployed Older Workers: Many Experience Challenges Regaining Employment and Face Reduced Retirement Security, GAO 12-445 (Washington, D.C.: April, 2012). 


\section{Up to an Estimated 35 Percent of Older Workers Report They Can Reduce Work Hours, but Few Actually Do}

In 2014, most older workers ages 61 to 66 worked full time, though many reported that they could reduce their work hours. ${ }^{23}$ We analyzed Health and Retirement Study (HRS) data from 2004-2014, focusing on a group of people who were born from 1948 to $1953 .{ }^{24}$ In 2004, when this cohort, known as the Early Baby Boomers, was 51 to 56 years old, an estimated 29 percent responded affirmatively when sked whether they could reduce their hours. Ten years later, when this group was 61 to 66 years old, of those Early Boomers still working, an estimated 35 percent said they could reduce their hours (see fig. 2).

\footnotetext{
${ }^{23}$ This is in response to the HRS question, "Could you reduce the hours in your work schedule?"

24 The Health and Retirement Study designates this group as the "Early Baby Boomer" cohort, one of six age cohorts included in the survey. Individuals in this cohort were first interviewed in 2004 and then re-interviewed every two years. This group would have been 51 to 56 in 2004, the first year they were included in the survey, and 61 to 66 in 2014, the last year for which we have complete data. This cohort began transitioning to retirement from 2004-2014, going from an estimated 10 percent of respondents indicating they were retired or partly-retired in 2004, to an estimated 53 percent indicating they were retired or partly-retired by 2014. For more information on the HRS sample and cohort definitions, see "Getting Started With the Health and Retirement Study," Version 1.0, 2006, Accessed 2/21/2017. http://hrsonline.isr.umich.edu/sitedocs/dmgt/IntroUserGuide.pdf
} 
Figure 2: Percentage of Early Baby Boomers answering "Yes" to 'Could you reduce the hours in your work schedule?'

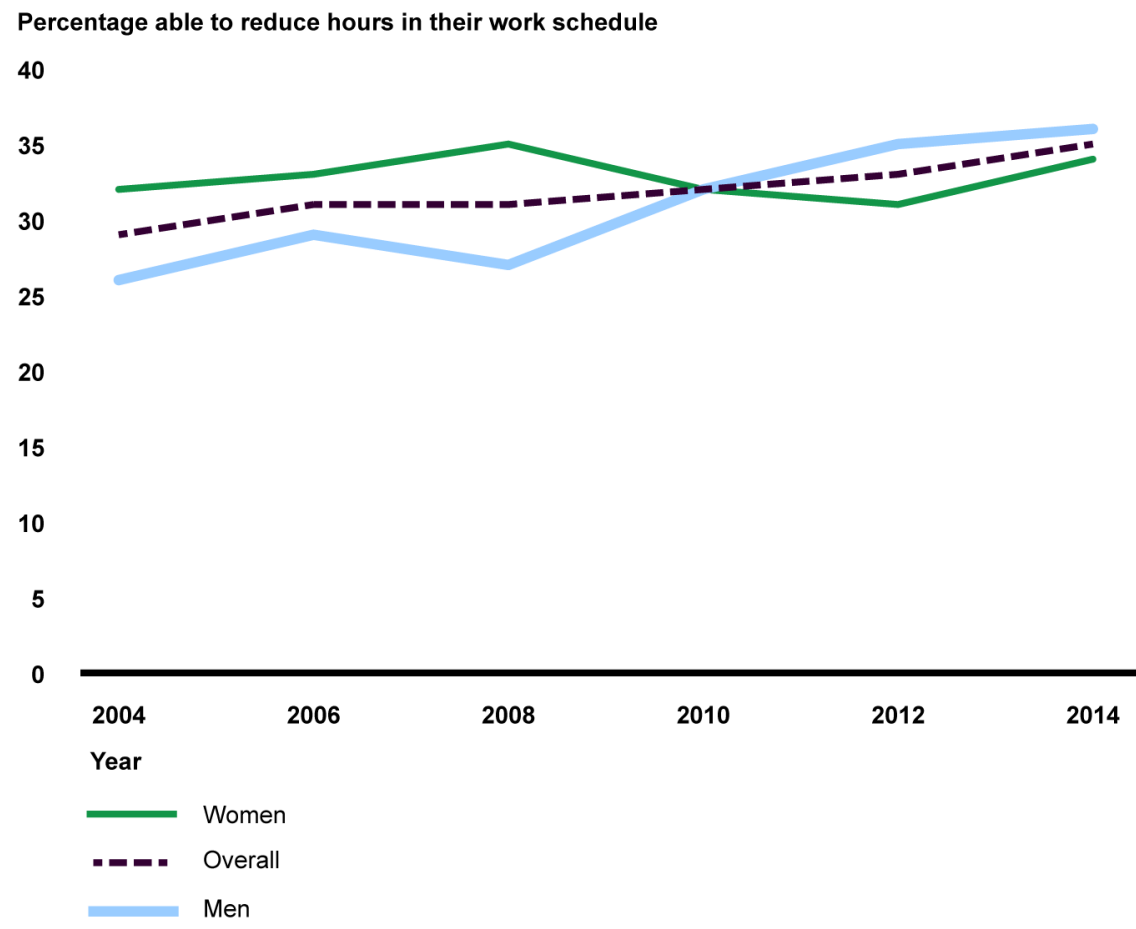

Source: GAO analysis of Health and Retirement Study, Early Baby Boomer Cohort data. I GAO-17-536

Note: Early Baby Boomers were born from 1948 to 1953 and were 51-56 years old in 2004 and 61-66 years old in 2014. Estimates and standard errors were calculated using the balanced repeated replication (BRR) method. Estimates used to generate this graphic are statistically significant at the $p<.05$ level or better and the $95 \%$ confidence interval is approximately $+/-5$ percentage points or less for all estimates.

Between 24 and 29 percent of Early Baby Boomers plan to gradually transition to retirement by reducing their hours, which is more than the percentage who plan to stop working altogether (see fig. 3). Similarly, GAO reported in 2015 that about 26 percent of workers ages 55-64 planned to work part time, while 18 percent planned to stop working altogether. ${ }^{25}$

25 GAO-15-419. 
Figure 3: Selected Retirement Employment Strategies of Early Baby Boomers Still Working At Time of Survey, 2004-2014

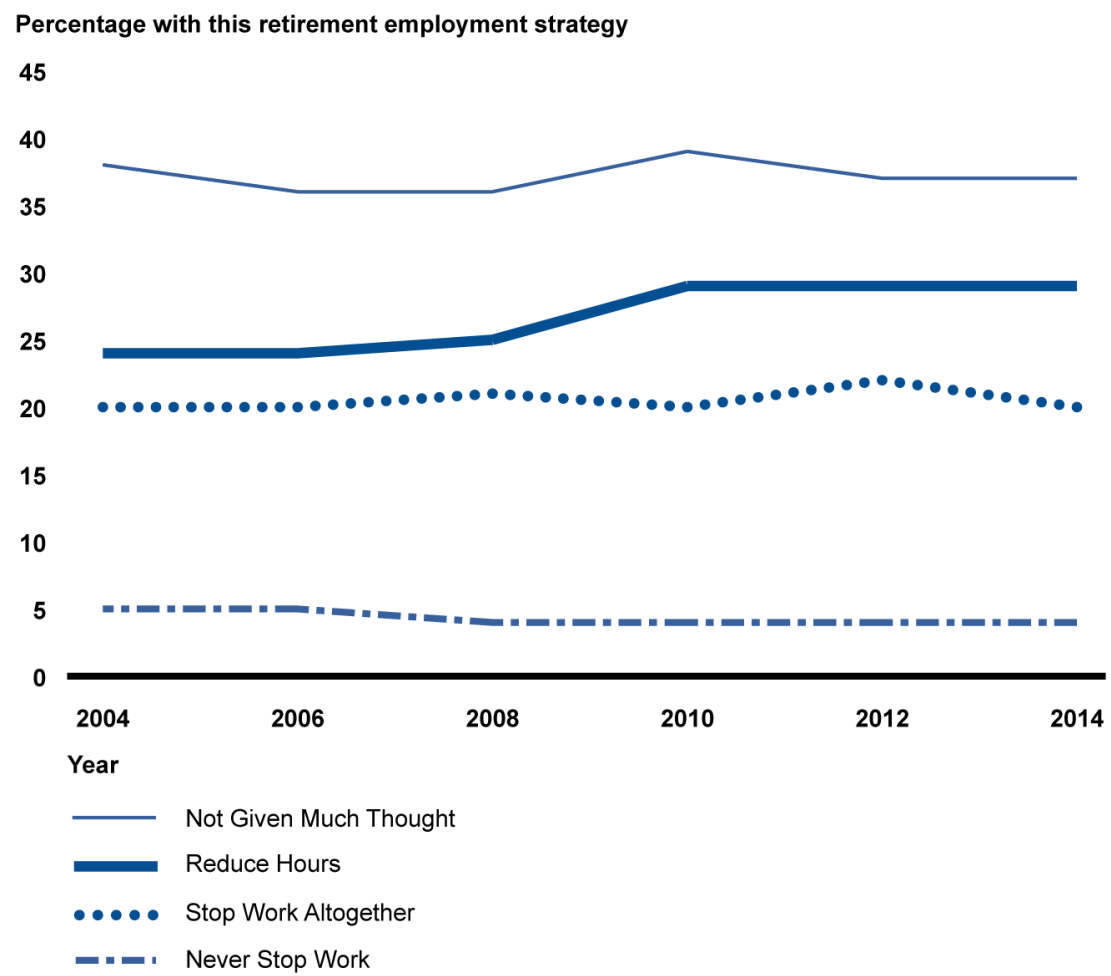

Source: GAO analysis of Health and Retirement Study, Early Baby Boomer Cohort data. | GAO-17-536

Note: Early Baby Boomers were born from 1948 to 1953 and were 51-56 years old in 2004 and 61-66 years old in 2014. Estimates and standard errors were calculated using the balanced repeated replication (BRR) method. Estimates used to generate this graphic are statistically significant at the $p<.05$ level or better and the $95 \%$ confidence interval is approximately $+/-3$ percentage points or less for all estimates.

For most years we analyzed, between 16 and 18 percent of the cohort approaching retirement said they would be interested in reducing their hours even if their pay was also reduced proportionally. This percentage increased to 22 percent in 2014 as the cohort aged (see fig. 4). In all years within this time period, more women than men in this age cohort expressed willingness to accept lower pay for reduced work hours. 
Figure 4: Percentage of Early Baby Boomers Who Would Like to Reduce Hours Even If Earnings Reduced Proportionally, 2004-2014

Percentage who would like to reduce hours even if pay also reduced

30

20

15

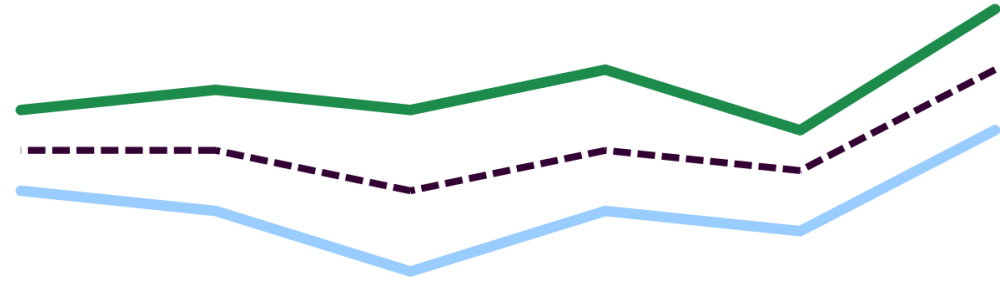

10

5

0

\begin{tabular}{|c|c|c|c|c|c|}
\hline 2004 & 2006 & 2008 & 2010 & 2012 & 2014 \\
\hline \multicolumn{6}{|l|}{ Year } \\
\hline 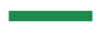 & Women & & & & \\
\hline "- & Overall & & & & \\
\hline 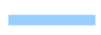 & Men & & & & \\
\hline
\end{tabular}

Source: GAO analysis of Health and Retirement Study, Early Baby Boomer Cohort data. | GAO-17-536

Note: Early Baby Boomers were born from 1948 to 1953 and were 51-56 years old in 2004 and 61-66 years old in 2014. Estimates and standard errors were calculated using the balanced repeated replication (BRR) method. All estimates used to generate this graphic are statistically significant at the $p<.05$ level or better and the $95 \%$ confidence interval is $+/-6$ percentage points or less for all estimates.

However, over the period we analyzed, data indicate that fewer Early Baby Boomers actually retired gradually than said they would be interested in reducing their hours. Based on our analysis of HRS, in 2014, as the Early Baby Boomer cohort approached retirement, the number of individuals who were partially retired was about 11 percent. ${ }^{26}$ This number was lower in 2004-at about three percent-when the cohort was younger. The percentage who were classified as partly retired in 2014 is

\footnotetext{
${ }^{26}$ If an HRS respondent is working part time and mentions retirement, the individual is classified as partly retired; if there is no mention of retirement, they are classified simply as working part time. A mention of retirement may be made when the respondent is asked about employment status or asked whether they consider themselves retired.
} 

interest in reducing hours as they approach retirement (see fig. 5). ${ }^{27}$

\section{Figure 5: Ability, Interest, and Realization of Reduced Working Hours among 61- to 66-Year-Olds, 2014}

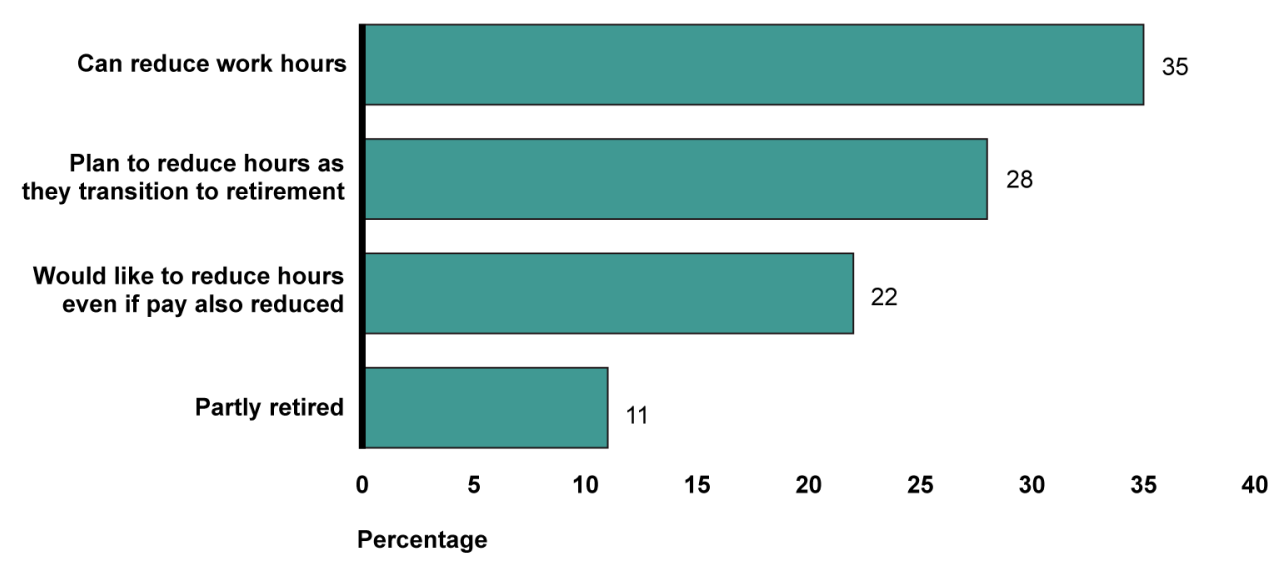

Source: GAO analysis of Health and Retirement Study, Early Baby Boomer Cohort data. | GAO-17-536

Note: All estimates in this graphic are based on analysis of responses by the Early Baby Boomer cohort, those born 1948 to 1953. All estimates used to generate this graphic are statistically significant at the $p<.05$ level. The $95 \%$ confidence intervals for estimates in this figure are within $+/-5$ percentage points.

27 The recession of 2007-2009 may have affected these results. For example, because the Early Baby Boomers were in the process of transitioning to retirement when the recession occurred, the number who are partially retired may have been depressed by late career job losses that made workers fully retired. 
What is Retirement?

Retirement can come in many forms, though it generally refers to the process of ceasing to work for pay. Oftentimes, retirement evokes an image of an older worker simply stopping work at a particular age (typically 65) and beginning to receive Social Security or other forms of retirement income. In other cases, retirement can be more gradual, such as with phased retirement, in which a worker eases into retirement by working part time with the same employer. In still further cases, retirement can be a lengthier process. For example, older workers can leave their career job and switch to a different job, either part time or full time; they can move in and out of the labor force throughout their older years; or they can cease working for pay but begin volunteering full time. Some of these options may allow a worker to draw down retirement savings or collect pensions while continuing to work. In this report, we acknowledge that retirement does not look the same for everyone.

Source: GAO analysis. | GAO-17-536
Other studies analyzing HRS data had findings similar to ours, namely that relatively few workers gradually retire from their career jobs, and that more of those workers who gradually retire have higher-paying jobs than workers who do not gradually retire. Specifically, four studies we reviewed also used HRS to examine the percentage of older workers who gradually retire. The most recent of these studies estimated that only 11 percent of men and 6 percent of women in the Early Baby Boomer cohort gradually retired from their full-time career jobs. It also found that those workers are more likely to have higher-paying jobs. For example, among the Early Baby Boomer cohort, an estimated 7 percent of men who earned up to $\$ 50$ per hour gradually retired, compared to 19 percent of men who earned over $\$ 50$ per hour. ${ }^{28}$ (For a discussion of what retirement is, see sidebar.)

While there may be unobserved barriers to a gradual reduction in hours, there are concrete financial reasons why more workers may plan to retire gradually than actually do. First, gradually retiring may have consequences for employer-provided health and pension benefits and no measures to address them..$^{29}$ Our analysis of HRS data indicates that among workers ages 61 to 66 in 2014 who said they could reduce their work hours, about 33 percent said their health insurance benefits would

\footnotetext{
${ }^{28}$ Although this study used an appropriate methodological approach to report on the percent of HRS respondents who gradually retired from their full-time career jobs, the authors do not report using sample weights in their analysis. As a result, these estimates may be biased relative to the total population of Early Baby Boomers and should not be interpreted as describing the retirement patterns of all U.S. workers. This analysis included workers who participated in formal phased retirement programs as well as those who had informal arrangements with their full-time career employer to gradually reduce their hours. It did not include those who changed employers. Kevin E. Cahill, Michael D. Giandrea, and Joseph F. Quinn, "Retirement Patterns and the Macroeconomy, 19922010: The Prevalence and Determinants of Bridge Jobs, Phased Retirement, and Reentry Among Three Recent Cohorts of Older Americans," The Gerontologist, vol. 55, no. 3 (2015).

${ }^{29}$ For example, GAO previously reported that part-time workers are less likely to be eligible to participate in workplace retirement plans than full-time employees and employers are not required to provide benefits to part-time employees. See GAO, Retirement Security: Federal Action Could Help State Efforts to Expand Private Sector Coverage, GAO-15-556 (Washington, D.C.: Sept. 10, 2015). Additionally, employers may exclude workers from participating in a qualified plan if they work fewer than 1,000 hours per year, or about 19 hours per week. GAO previously reported that women are more likely than men to work part time. See GAO, 401(K) Plans: Effects of Eligibility and Vesting Policies on Workers' Retirement Savings, GAO-17-69 (Washington, D.C., Oct. 21, 2016). Prior GAO work has also shown that women have less retirement income than men, on average. See GAO, Retirement Security: Women Still Face Challenges, GAO-12-699 (Washington, D.C., July 19, 2012).
} 
be reduced or eliminated and 23 percent said their eligibility for pension benefits would be affected. ${ }^{30}$ Another factor that may affect individuals' ability to gradually retire is Americans' low savings leading into retirement and a desire to maximize earnings prior to retiring fully. As we reported in 2015, most households approaching retirement have low savings. ${ }^{31}$

Further, many workers retire sooner than they thought they would and therefore may not be able to carry out their plan to reduce work hours leading into retirement. Specifically, despite increases in older workers' overall labor force participation, HRS respondents retired, on average, sooner than they expected. In the HRS cohort approaching retirement between 2004 and 2014, the average difference between planned retirement year and actual retirement year was about 6 years. ${ }^{32}$ Nearly 70 percent of respondents who had a plan for when to retire ended up retiring prior to their planned retirement year. About 17 percent of respondents retired later than expected.

Depending on the year, up to one-half of cohort members retiring from 2004 to 2014 said they felt forced to retire; the percentage was higher for those who retired in their 50 s than in their $60 \mathrm{~s} .{ }^{33}$ That said, as the cohort aged, more respondents said they wanted to retire when they did than said they felt forced to retire. In our prior work we reported that individuals approaching retirement tend to overestimate their ability to keep working past retirement age and often have to retire for reasons they did not

\footnotetext{
30 The 95 percent confidence interval for workers saying their health insurance benefits would be reduced or eliminated was $+/-7$ percent, and the 95 percent confidence interval for workers saying their eligibility for pension benefits would be affected is $+/-9$ percent.

31 GAO-15-419.

32 Based on GAO calculation, this is the absolute value of mean planned retirement year minus actual retirement year for all individuals in the cohort who have both a planned and actual retirement year. The gap between planned and actual retirement does not take into account those who were still working but did not have an actual retirement date at the time of survey, nor does it take into account those who might have died before retiring.

${ }^{33}$ The survey question does not ask why respondents felt forced to retire; the data do not allow for a distinction between people who felt forced to retire by professional circumstances versus personal circumstances. The survey also does not ask questions about the role of the 2007-2009 recession, although this may have been a factor in forcing people to retire when they would rather not.
} 
anticipate, such as health problems, changes at their work place, or caregiving responsibilities. ${ }^{34}$

\section{Formal Phased Retirement Programs Are Not Common, with Larger Employers and Those with Technical and Professional Workforces More Likely to Offer Them}

Phased Retirement
Programs Are Not as
Common as Informal
Arrangements, and the
Number of Programs
Remained Steady in
Recent Years

Phased Retirement Programs Are Not as Common as Informal Arrangements, and the

Remained Steady in Recent Years
While no nationally representative data on the prevalence of phased retirement exist, one large study we reviewed and experts we interviewed indicated that formal phased retirement programs are relatively uncommon. The largest study we reviewed, a 2016 Society for Human Resource Management (SHRM) survey, found that an estimated 5 percent of all employers in SHRM's large membership base offer a formal phased retirement program. ${ }^{35}$ Moreover, experts we spoke with confirmed that formal phased retirement programs are not common. Of the 16 experts we interviewed, 14 said that such programs were either not common or were rare. ${ }^{36}$

\footnotetext{
34 GAO-15-419.

${ }^{35}$ Society for Human Resource Management, 2016 Employee Benefits: Looking Back at 20 Years of Employee Benefits Offerings in the U.S. (Alexandria, VA: June 2016). SHRM defines a formal phased retirement program as a formal program that provides a reduced schedule and/or responsibilities prior to full retirement. This estimate could be different from the percentage of U.S. employers as a whole that offer formal phased retirement, which is unknown. SHRM's membership base consisted of 275,000 human resources professionals in a variety of industries across privately owned for-profit, nonprofit, publicly owned for-profit, and government organizations. According to SHRM, a greater percentage of small employers responded to the survey than are represented in their membership base.

${ }^{36}$ Two of the 16 experts did not speak to the prevalence of such programs.
} 
The other two studies providing information on the prevalence of phased retirement programs we reviewed also found that such programs were not widely adopted by employers, though the studies did not specify whether the programs were formal and looked only at employers with a certain number of workers. ${ }^{37}$ Further, the findings from these two studies likely overstate the prevalence of phased retirement among employers overall because while a substantial proportion of U.S. firms have a small number of workers, such small firms were underrepresented in these studies. ${ }^{38}$

37 Specifically, one of the studies, conducted by the Transamerica Center for Retirement Studies, surveyed employers with 10 or more workers and estimated that about a quarter of employers offer a work-related program to help older workers transition into retirement by reducing hours. Transamerica Center for Retirement Studies, The Current State of 401(k)s: The Employer's Perspective. Transamerica Institute (June, 2016). The other study, conducted by MetLife, looked at employers with 1,000 or more workers and estimated that about a third have introduced formal phased retirement programs in which workers go part time to ease into retirement. This study had a relatively small sample size of 240. MetLife, The Emerging Retirement Model Study: A Survey of Plan Sponsors. Metropolitan Life Insurance Company (December 2009).

${ }^{38}$ About 79 percent of firms have fewer than 10 workers, according to 2011 data from the U.S. Small Business Administration, based on data provided by the U.S. Census Bureau. About 90 percent have fewer than 20 workers, and 99.8 percent have fewer than 1,000 workers. About 11 percent of workers are in firms with fewer than 10 workers, 18 percent are in firms with fewer than 20 workers, and 54 percent are in firms with fewer than 1,000 workers. 
Formal vs. Informal Phased Retirement In this report we discuss both formal phased retirement programs and informal phased retirement arrangements, similar concepts that both involve easing into retirement while remaining with the same employer.

For purposes of this report, formal phased retirement is an employer-based program in which older workers can reduce their working hours in order to transition into retirement. While studies we reviewed all used variations on this definition, they all included programs that employers offered to workers prior to full retirement. For example, a 2016 Society for Human Resource Management study most closely described formal phased retirement as we use the term, defining it as a formal reduction in schedule and/or responsibilities prior to full retirement. A study by the Transamerica Center for Retirement Studies the same year described phased retirement as a work-related program to help workers age 50 and older transition into retirement by reducing hours and shifting from full time to part time, and an earlier MetLife study described such programs as part-time work programs to help employees ease into retirement.

In comparison, informal phased retirement arrangements are situations in which a worker remains with the same employer but eases into retirement through an informal channel rather than a program. For example, some workers nearing retirement may be allowed to have part-time status though there is no formal policy (sometimes referred to as an ad hoc arrangement). Alternately, an employee may retire and then be rehired by the same employer (known as retire/rehire).

Source: GAO analysis. | GAO-17-536
Informal phased retirement arrangements are generally more common than formal phased retirement programs, according to the two studies we reviewed that examined this topic and 10 of the 16 experts we interviewed. ${ }^{39}$ (See sidebar for more information about formal and informal phased retirement.) According to SHRM's 2016 study, 11 percent of employers in their membership base reported that they offered informal phased retirement in 2016 , which is about twice as many as reported they offered formal phased retirement. Another study found that a majority of employers with 20 or more workers could "work something out" vis-a-vis phased retirement, although only one-third of these had a formal written policy. ${ }^{40}$

There is little indication that the prevalence of phased retirement has changed much in recent years, according to the three studies we reviewed on this topic. The SHRM study examined formal phased retirement programs specifically, reporting that their prevalence has remained relatively low among its members over the last decade. ${ }^{41}$ These programs may be unlikely to increase, as SHRM reports less than one percent of their members plan to begin offering such a program in the next year. Two different studies examined a combination of formal and informal phased retirement and found the prevalence unchanged in recent years. One study looked at the time period between 2008 and 2014 and found no statistically significant difference over time in the percentage of employers with 50 or more workers offering phased retirement. ${ }^{42}$ One small study that included large domestic and international employers found the proportion of employers offering phased retirement relatively unchanged from 2010 to $2015 .{ }^{43}$

\footnotetext{
39 The other six experts we interviewed did not speak to this topic.

40 This study may overstate the prevalence because a substantial proportion of firms in the study have larger number of workers compared to U.S. employers overall. This study was based on data collected in 2001-2002. Robert Hutchens and Karen Grace-Martin, Employer Willingness to Permit Phased Retirement: Why Are Some More Willing than Others? Industrial and Labor Relations Review, vol. 59, no. 4 (July, 2006).

${ }^{41}$ According to SHRM, the prevalence of formal phased retirement has remained at or below 13 percent since 2005 .

42 Kenneth Matos and Ellen Galinsky, 2014 National Study of Employers, Families and Work Institute (2014).

43 Trends in Workplace Flexibility, WorldatWork (2015).
} 


\begin{tabular}{l}
\hline Larger Employers and \\
Those with Technical and \\
Professional Workforces \\
Are More Likely to Offer \\
Phased Retirement \\
Programs
\end{tabular}

More large employers offer phased retirement than small employers, according to the three studies we reviewed that examined the number of workers at employers offering phased retirement. The SHRM survey found that its members with 2,500 to 9,999 workers are significantly more likely to offer formal phased retirement programs than those with fewer than 500 workers (an estimated 16 percent, compared to 5 percent for employers with 100 to 499 workers and 4 percent for employers with 1 to 99 workers). ${ }^{44}$ Another study reported that a slightly larger percentage of employers with 500 or more workers offer phased retirement programs than employers with 10 to 99 workers (30 percent compared to 25 percent), though the difference was not statistically significant. ${ }^{45}$ One further study found that phased retirement occurred more at employers with 500 or more workers than at those with less than 500 workers (77 percent compared to 39 percent). ${ }^{46}$

Employers in certain industries are more likely to offer phased retirement, particularly those in industries with technical and professional workforces. Consulting, education, and high-tech were among the industries most likely to offer phased retirement, according to the three studies we reviewed that included information on formal and informal phased retirement by industry. According to SHRM's survey of its members, industries most likely to offer formal phased retirement include education, government, utilities, consulting, and high-tech (see table 2). For example, 12 percent of SHRM members in the education industry offer formal phased retirement, and among the subgroup of higher education

\footnotetext{
44 This study examined employers of all sizes. Organizations with 10,000 or more workers were excluded from this analysis due to small sample sizes.

45 This study examined employers with 10 or more workers. Transamerica Center for Retirement Studies (2016).

46 This study examined employers with 20 or more workers and was based on data collected in 2001-2002. Hutchens and Grace-Martin (2006).
} 
members, 23 percent offer it. Industries least likely to offer formal phased retirement include real estate/rental leasing and retail/wholesale trade. ${ }^{47}$

Table 2: Estimated Percentage of Society for Human Resource Management Members Offering Formal Phased Retirement Programs, by Selected Industry, 2016

\begin{tabular}{lr}
\hline Industry & $\begin{array}{r}\text { Estimated Percentage } \\
\text { of Members in that Industry with } \\
\text { Formal Phased Retirement Programs }\end{array}$ \\
\hline Education & $12 \%$ \\
\hline State and Local Government & $11 \%$ \\
\hline Utilities & $10 \%$ \\
\hline Consulting & $7 \%$ \\
\hline High Tech & $7 \%$ \\
\hline All Industries & $5 \%$ \\
\hline
\end{tabular}

Source: Society for Human Resource Management 2016 survey data | GAO-17-536

\footnotetext{
${ }^{47}$ According to SHRM, 1 percent of real estate/rental leasing and 3 percent of retail/wholesale trade employers in its membership base offer formal phased retirement. For informal phased retirement, some of the industries with the highest prevalence also have a technical and professional workforce. Industries most likely to offer informal phased retirement include insurance (20 percent), finance (15 percent), biotech (13 percent), state and local government (13 percent), and manufacturing (13 percent). Industries least likely to offer informal phased retirement include telecommunications (6 percent), transportation/warehousing (7 percent), retail/wholesale trade (7 percent), real estate/rental leasing (7 percent), and arts/entertainment/recreation ( 7 percent).
} 
Phased Retirement in the Federal Government

In 2014, the Office of Personnel Management (OPM) issued final regulations on implementation of agency-level federal phased retirement programs, and beginning in 2015 some federal agencies began implementing their programs. While each agency has discretion over certain aspects of their program, should they choose to implement one, other features apply to all federal phased retirement programs. For example, there is an age and length of service requirement and participants must have been employed on a full-time basis for three years prior to entry in phased retirement. While in phased retirement, all participants are currently required to work 50 percent time, and they receive half their previous pay and approximately half of their annuity. Participants' health insurance and group life insurance premiums are the same as if working full time. They are generally required to serve a mentorship or knowledge and skill transfer role for at least 20 percent of their working hours. Upon full retirement, participants' annuity benefits are recalculated as a composite annuity that incorporates their service while in phased retirement. Given that agencies are still implementing their programs, it is too early to assess the federal program's overall effect.

Source: GAO analysis of OPM policies and guidance. | GAO-17-536
The other two studies examining data on prevalence examined both formal and informal phased retirement and found patterns similar to the SHRM study. One older study of employers with more than 20 workers found that establishments in the service sector, especially those in health, education, and social services, are more likely to permit formal and informal phased retirement. ${ }^{48}$ In contrast with the SHRM survey, this study found that public administration and transportation/communications/utilities industries were less likely to permit formal and informal phased retirement. Lastly, one study based on a small survey of large domestic and international employers found that consulting, professional, scientific, and technical services organizations were most likely to offer formal and informal phased retirement (41 percent) while manufacturing employers were least likely to offer it (24 percent). ${ }^{49}$ (See sidebar for information on phased retirement in the federal government.)

Employers with professional and technical workforces may have more of a reason to retain older workers via phased retirement precisely because their workers tend to be highly skilled. Nine of the 16 experts we interviewed explained that industries with skilled workers or with labor shortages have motivation to offer formal phased retirement programs in part because their workers are hard to replace. For example, one expert we interviewed described a company with manufacturing staff who were highly skilled in engineering or the complex manufacturing process. The company saw a need to offer phased retirement to retain these staff, who would be hard to replace.

Certain employers may also choose to offer phased retirement to their most skilled or higher ranking employees rather than to others. For example, one study found that among large employers offering phased retirement, a smaller percentage offered phased retirement to hourly workers than offered it to executives and salaried workers. ${ }^{50}$ Another article we reviewed described how technological advances have

\footnotetext{
48 This study was based on data collected in 2001-2002. Hutchens and Grace-Martin (2006).

${ }^{49}$ WorldatWork (2015). Other industries included finance and insurance (35 percent) and health care and social assistance (32 percent). The survey was of WorldatWork members, who typically work in large companies in North America.

50 WorldatWork (2015). The survey was of WorldatWork members, who typically work in large companies in North America.
} 
increased the demand for skilled labor and that phased retirement may be better to manage skilled workers, managers and professionals than clerical and blue-collar workers. ${ }^{51}$

Some of the industries most likely to offer phased retirement already have part-time opportunities for workers, which may have to do with how their work is structured and the common practices in those industries. For example, according to 2016 CPS data, an estimated 26 percent of workers in education and health services work less than 35 hours per week, compared to 11 percent in manufacturing. ${ }^{52}$ The nature of the job likely also plays a role, as it may be logistically easier for a professor, for example, to teach fewer courses than for an assembly-line worker to reduce the hours on her shift. For instance, two of the publications we reviewed explained that some employers feel phased retirement may not be a good "fit" with their job structure. As one expert told us, some industries have embraced flexible work arrangements while others have not. Establishments more open to part-time work or flexible hours also tended to be more open to phased retirement, according to the two studies we reviewed that examined employer characteristics. ${ }^{53}$ One of these studies also found that establishments that permitted informal or formal phased retirement tended to have policies that were supportive of part-time work, such as health insurance and paid vacations for part-time workers. ${ }^{54}$

There are other reasons that employers may not be interested in phased retirement or retaining older workers, according to four of 11 publications we reviewed that described potential obstacles to phased retirement. For example, two articles cited bias or beliefs among some employers that older workers are less productive or less valued than younger workers. One of these and another article described how health care costs can be expensive for older workers. One additional study reported that the

\footnotetext{
${ }^{51}$ For this report, we reviewed nine articles written by experts in the field of retirement programs. These articles do not present original research but instead describe the perspectives of these experts based on their work in the retirement field.

52 https://www.bls.gov/cps/cpsaat21.htm, accessed April 19, 2017.

53 These studies were based on data collected in 2001-2002. Hutchens and Grace-Martin (2006) and Robert Hutchens, Worker Characteristics, Job Characteristics, and Opportunities for Phased Retirement, Labour Economics 17: 1010-1021 (2010).

54 This study was based on data collected in 2001-2002. Hutchens and Grace-Martin (2006).
} 
obstacle most commonly cited by large employers who do not offer phased retirement is that there is no expressed interest from employees. ${ }^{55}$ This may be especially true in workplaces with few older workers.

Designing Phased Retirement Programs Can Be Challenging, According to Experts, Employers, and Publications, but Some Employers Report Benefits in Doing So

Key Cited Challenges to Designing a Phased

Retirement Program Include Compliance with IRC Nondiscrimination Provisions and Employment-related Discrimination Laws
Employers face potential challenges in complying with various laws and regulations when designing a phased retirement program, according to experts and employers we interviewed and the publications we reviewed..$^{56}$ Of large employers, 71 percent agreed that "regulatory complexities and ambiguities involving federal tax and age discrimination laws impact their organization's ability to offer a phased retirement program," according to a small MetLife study of employers with 1,000 or more workers. ${ }^{57}$ One of the experts we interviewed described a general sense of fear or uncertainty among employers about laws and regulations and their possible application to phased retirement arrangements. Based

\footnotetext{
${ }^{55}$ WorldatWork (2015). The survey was of WorldatWork members, who typically work in large companies in North America.

${ }^{56}$ We conducted semi-structured interviews with 9 employers: 6 employers had formal phased retirement programs and 3 did not. Of the 3 without formal phased retirement programs, 2 had programs that were not written down or formalized, but that otherwise met our definition of phased retirement and 1 employer considered, but did not implement, phased retirement. Of the 16 experts we interviewed, 12 identified at least 1 possible compliance challenge and 5 of the 12 identified 2 possible compliance challenges. Of the 11 publications we reviewed, 6 mentioned at least one possible compliance challenge.

57 MetLife (December 2009).
} 
on employer and expert interviews and publications we reviewed, some employers report facing challenges with Internal Revenue Code (IRC) nondiscrimination provisions, employment-related discrimination laws, the defined benefit pension formula, health care coverage, and in-service distributions from pension and savings plans. ${ }^{58}$

IRC nondiscrimination provisions: According to experts, publications, and employers, IRC provisions regarding discrimination can be a challenge when designing phased retirement programs. These provisions generally prohibit a qualified plan from discriminating in favor of highly compensated employees. ${ }^{59}$ Failure to comply may result in loss to the employer of the tax benefits of providing an ERISA qualified plan. In addition, workers in a plan that is no longer qualified may lose tax benefits and certain protections. Over the past several decades, private sector employers have shifted from providing a large share of retirement benefits through DB plans to relying much more heavily on DC plans. ${ }^{60}$ The nondiscrimination rules apply to both DB and DC plans. ${ }^{61}$ The MetLife survey found that an estimated 51 percent of large employers agreed that "the retirement plan nondiscrimination rules can be an obstacle to an effective phased retirement program for their organization." 62 Of the 11 publications we reviewed, five reported the nondiscrimination provisions

\footnotetext{
58 Additional challenges noted by employers we interviewed included administrative requirements, completing the same amount of work with fewer full-time workers, and the burden on full-time staff.

59 These provisions, enforced by the IRS, require qualified plans to demonstrate that they do not discriminate by showing: 1) they do not favor highly compensated employees in terms of plan coverage, and 2) they are not providing disproportionate contributions or benefits to highly compensated employees. 26 U.S.C. $\S \S 401(a)(4)$ and 410(b).

60 In 1975 there were about 103,346 DB plans and 207,748 DC plans. By 2014, the number of DB plans has decreased to 44,869 while the number of DC plans has increased to 640,334 . Data is from Form 5500 filings and excludes "one-participant plans." (U.S. Department of Labor, 2016).

${ }^{61}$ A defined benefit (DB) plan specifies the benefit that will be payable at retirement, typically in the form of an annuity that provides a monthly payment for life. It is usually based on a formula specified by the plan that often includes factors such as years of service and salary (for example, average of highest three or five years of earnings). A defined contribution (DC) plan specifies how much will go into an account within the retirement plan. Generally, workers contribute a percentage of their wages or a specific dollar amount to the account, and employers also have the option of making account contributions. The amount at retirement generally depends on the total contributions to the account and the total amount of returns on the investment of account funds.
}

62 MetLife (December 2009). 
in general were a challenge, as did seven of the 16 experts we interviewed. However, of the eight employers we spoke with that had DC plans and phased retirement programs, none identified the nondiscrimination rules as a challenge to setting up a phased retirement program in the context of their DC plan.

In contrast, one employer we interviewed had seriously considered a phased retirement program but ultimately did not implement one in part because the employer believed it could fail the nondiscrimination testing. It believed the IRS regulations limited its ability to provide the phased retirement program it wanted. The employer explained their view that if they offered phased retirement and gave partial service credits to phasing workers who were participating in the DB plan, and the credits were included in the nondiscrimination testing, it could fail the test due in part to their older workforce's longer service and therefore higher salaries.

According to eight of the 16 experts we interviewed, some employers, such as those providing specialized services, would prefer to choose only those workers with specific, difficult to replace skills for phased retirement, and often it is those workers who are highly paid. This potential challenge was also noted by four of the 11 publications we reviewed. For example, one of the experts said in his view if an employer wanted to incentivize phased retirement by offering additional 401(k) matching contributions, it would be discriminatory if it were offered only to highly compensated employees_-potentially those with the specific skills the employer wanted to retain. Specifically, the IRC nondiscrimination rules require that the group of employees who are eligible for phased retirement not be constituted in a way that favors highly compensated employees. This determination is made by comparing the extent to which highly compensated employees are eligible for phased retirement with the extent that other employees are eligible and takes into account the business reason for the selection of the eligible group. One expert observed that if a company does not have a business need to make all workers eligible for phased retirement, it must have a business need for selecting specific types of workers. He added that companies struggle to decide and define who should be eligible for pension and other benefits such as phased retirement.

Employment-related discrimination laws: According to experts and employers we interviewed, designing phased retirement programs for older workers also potentially brings employers face-to-face with age- and 
disability-related legal challenges. ${ }^{63}$ Of the 16 experts we interviewed, 10 noted as a challenge the potential of a phased retirement program violating ADEA and/or ADA protections against employment-related age or disability discrimination. The ADEA was also discussed in three of the 11 publications we reviewed. One article explained that deciding to offer phased retirement only to employees who have essential skills could expose the employer to ADEA claims, especially if the program denied enrollment to relatively old employees. Another expert pointed out that it could be considered discriminatory if it targeted the phased retirement program only to workers who were younger than age 62. Two employers commented that it is easier to allow an ad hoc agreement for a worker who wants to work fewer hours or to become a contractor than it is to have a formal phased retirement program.

According to four of the employers we spoke with and six of the publications we reviewed, the potential legal uncertainties and challenges that surround both nondiscrimination provisions and employment-related discrimination laws may discourage employers from establishing formal phased retirement programs, even though they and their employees may benefit from such programs. One expert we interviewed told us that phased retirement is a grey area under the age discrimination laws. Another told us there is a high level of concern about creating discriminatory phased retirement programs.

Calculation of defined benefit pensions: The benefit formula of some DB plans can be a potential challenge to designing a phased retirement program, according to seven of the 11 publications we reviewed.

According to those publications, depending on how the formula is designed, it could have a negative effect on working longer and be a disincentive for workers to participate in their employer's program. For example, if the benefit formula calculation takes into account the last 5 consecutive years of wages, and the worker participates in a phased

63 The ADEA prohibits an employer from, among other things, refusing to hire, discharging, or otherwise discriminating against an individual with respect to compensation, terms, conditions, or privileges of employment because of age. 29 U.S.C. $\S 623(a)(1)$. The term "compensation, terms, conditions, or privileges of employment" under ADEA includes "all employee benefits, including such benefits provided pursuant to a bona fide employee benefit plan." 29 U.S.C. $\$ 630(I)$. ADEA protections are limited to individuals who are at least 40 years of age. 29 U.S.C. $§ 631(a)$. Generally, Titles I and V of the ADA, among other things, prohibit employers from discriminating against a qualified individual on the basis of disability in regard to the hiring, advancement, or discharge of employees, employee compensation, job training, and other terms, conditions, and privileges of employment. 42 U.S.C. §§ 12111-12117, 12201-12213. 
retirement program that entails fewer work hours and lower wages, it could have a permanent effect on the worker's DB pension amount.

Seven out of 16 experts noted the potential challenge of determining how the benefit for a DB plan is calculated. For example, one expert said a major concern was that participating in phased retirement could reduce a worker's lifetime DB pension benefit if the benefit is based on the last 3 or 5 years of service. Another told us that if the employer made changes in the DB plan to accommodate the phased retirement participants, the employer would have to be very careful to do this in a nondiscriminatory way. Of the nine employers we interviewed, two had DB plans. One of the two commented that when they designed their phased retirement program, the DB plan was the most difficult piece to figure out.

Health care coverage: The provision of health benefits to participants in a phased retirement program can be a challenge, according to two of the 11 publications we reviewed. Employers may choose to offer group health coverage to their workers who work less than full time. These employers have to decide whether phasing workers will be covered. For active workers over age 65, Medicare is generally the secondary payer. If an employer provides health coverage to phasing workers, both older and younger than age 65 , the employer may have increased health care costs. According to two articles we reviewed, some employers may see this increased cost as a disincentive to implementing a phased retirement program. These articles noted the potential cost of providing health insurance for phasing workers.

However, health care coverage was provided for both full-time and phasing workers by all eight of the employers we interviewed who offered phased retirement. One pointed out that their health insurance subsidy is a major benefit to employees, and as a component of the phased retirement program, shows that the company respects and values its workers. Three of the eight employers required that the phasing worker complete a designated number of work hours per week or pay period to qualify for these health benefits. One of the three had two levels of coverage differentiated by age, hours worked, and tenure requirements.

In-service distributions: According to nine of the 16 experts we interviewed and three of the 11 publications we reviewed, workers may be unable to afford living on the reduced wage of phased retirement, which may make the programs unattractive to such workers. To afford living on the reduced wage of phased retirement, workers may need to withdraw income from their retirement savings accounts or start receiving 
DB benefits. However, in-service withdrawals are subject to age requirements, and not all plans allow in-service withdrawals. ${ }^{64}$ DB plans generally provide in-service distributions only to workers age 62 and older.

One article pointed out that DC plan participants generally may not receive, without penalty, distributions from a DC plan until they reach age 59 and $1 / 2$. The article noted that because few workers can afford to partially retire unless they receive retirement benefits, these provisions effectively rule out phased retirement before age $59 \frac{1}{2}$ for DC plan participants and age 62 for DB plan participants. Two of the experts we interviewed said that age 62 was too old to make a difference in early retirement decisions. One added this can be an issue in certain industries where workers may want to retire before age $62 .{ }^{65}$

This can be challenging for employers who may want to provide phased retirement to workers in their 50's. ${ }^{66}$ One article noted that employers with DB plans may want to offer phased retirement to their younger workers, preferably when they are eligible for early retirement under the plan provisions. One expert said that phased retirement could be very helpful for workers in physically demanding jobs, such as the service industry or building trades, that tend to wear out workers' bodies by their $50 \mathrm{~s}^{67}$

\footnotetext{
${ }^{64}$ By in-service withdrawals, we generally mean benefit distributions from qualified pension plans before a worker ceases working for the employer who sponsored that plan.

${ }^{65}$ With respect to distributions from the federal phased retirement program, Congress addressed the early distribution penalty by adding an exception to the penalty for phased retirement annuity payments under the Civil Service Retirement System and the Federal Employees Retirement System. 26 U.S.C. § 72(t)(2)(A)(viii).

66 The employers we spoke with had a variety of ages at which workers were eligible to participate in their employers' phased retirement program. See appendix II for more details.

67 Generally, the normal retirement age under a plan must not be an age earlier than the earliest age that is reasonably representative of the typical retirement age for the industry of the relevant covered workforce. Depending on a weighing of all the relevant facts and circumstances, a normal retirement age that is not lower than 55 and earlier than 62 may be found to be earlier than the earliest age that is reasonably representative of the typical retirement age for the industry of the relevant covered workforce. However, a normal retirement age that is lower than age 55 is presumed to be earlier than the earliest age that is reasonably representative of the typical retirement age for the industry of the relevant covered workforce unless the Commissioner determines otherwise based on the relevant facts and circumstances.
} 
Experts and Employers Interviewed Reported that Operating a Phased Retirement Program Requires On-going Compliance Activities and Attention to the Concerns of Managers
According to our interviews with experts and employers, operational challenges with phased retirement programs fall into two general categories: 1) on-going compliance activities with IRC nondiscrimination provisions and employment-related discrimination laws; and 2) administrative issues including the needs and concerns of managers.

\section{IRC nondiscrimination provisions and employment-related} discrimination laws: According to five of the 11 publications we reviewed and seven of the 16 experts we interviewed, compliance with the nondiscrimination provisions can be an ongoing challenge. ${ }^{68}$ Depending on a retirement plan's eligibility criteria under a phased retirement program, there may be complaints of employee discrimination. For example, one employer we interviewed said they did not advertise their program partly because it is not offered in every business unit. Both an expert and an employer told us that the paperwork required to stay in compliance with the nondiscrimination provisions can be burdensome and is easy to get wrong. According to two of nine employers and 10 of 16 experts we interviewed, ongoing activities related to compliance with ADEA- and ADA-related discrimination laws can also be a continuous challenge.

Administrative and manager concerns: Seven of the nine employers we interviewed told us that phased retirement programs present administrative challenges. Six of them told us their managers were concerned that they have to get the same amount of work completed with fewer work hours from phased retirement participants. Administering the payroll was also cited as an ongoing challenge by another employer, who told us it can be difficult to track these workers' time and to account for merit increases and bonuses. Another employer said it is a challenge both to arrange workers' schedules and make sure clients' needs are met. One employer said it takes managers extra time to help with knowledge transfer and adjustments due to changes in workers' schedules.

Two employers told us their managers also were concerned about the phased retirement program in the context of their organization's financial

\footnotetext{
68 In 2015, we reported that employers may be reluctant to make changes to their Qualified Default Investment Alternative in part because of fear that a change could expose them to additional fiduciary liability or potential litigation. GAO, 401(k) Plans: Clearer Regulations Could Help Plan Sponsors Choose Investments for Participants, GAO-15-578 (Washington, D.C.: Aug. 25, 2015).
} 
and personnel rules and processes because, ultimately, the program could result in reduced budgets for the individual work units. One employer explained that managers have to do their planning and budgeting as if the phased retirement participants were working full time. Another employer described a similar budget/staffing situation. This employer told us that each division is funded by head count (number of staff), so if the division has a phased retirement participant, the manager will not necessarily have the budget to hire a full time replacement because the head count remains the same.

\section{Employers We Interviewed \\ Who Had Overcome \\ These Cited Challenges \\ Reported Benefits from \\ Phased Retirement \\ Programs}

\author{
Approaches to Overcome \\ Cited Challenges
}

In light of these cited challenges, employers we spoke with who had implemented phased retirement programs told us they were able to address various design and operational challenges using different approaches.

IRC nondiscrimination provisions and employment-related discrimination law approaches: Of the nine employers we interviewed, five reported that they overcame potential IRC nondiscrimination challenges applicable to their retirement plans by allowing all of their workers who met basic age and years of service requirements to participate in the phased retirement program. ${ }^{69}$ For example, one employer opened phased retirement to all U.S. employees age 60 and older with 5 years of service at the company. Another opened the program to all workers age 55 and older with 10 years tenure and at least "achieved expectations" on their performance evaluations. Three employers had no eligibility requirements at all. One employer commented that their program's open eligibility was in line with the inclusive culture of the company.

${ }^{69}$ Of these five, all had DC plans. 
The three employers with specialized or highly skilled workers said they overcame the challenge by making their phased retirement program available to those workers they identified as meeting a "business need." For example, one employer told us that eligibility for their phased retirement program was up to management and management's perception of the business need to retain staff, and the ability to fill the phasing worker's position on a part-time basis. They said that some positions require full-time staff, for example, customer service positions. Another employer said they require the worker to submit an enrollment form with the manager's signature both at initial application and every year of program participation thereafter. According to this employer, this procedure ensures there is a business need for the worker to participate in the program.

To allay employment-related discrimination concerns, employers reported using different approaches. One employer told us managers have very strict guidelines about what can and cannot be said in a discussion about phased retirement. Specifically, a manager cannot offer advice or ask leading or specific questions about age or retirement. Another employer, who does not advertise their program, told us they wait for the "windows" when workers bring it up or at performance reviews to discuss the program. Similarly, another employer said that when an employee tells human resources they are interested in retirement, human resources asks if phased retirement is an option. One of the employers, who does not have a written policy on phased retirement, told us the individual worker and the company representative work together on phased retirement to "make it work." 
How One Employer Met the Challenge of Defined Benefit Plan Accruals

One employer we spoke with told us it calculates the benefit amount for its defined benefit (DB) plan using a consecutive 5-year average of wages. Because workers in its phased retirement program only work four days per week and receive 80 percent of their full-time pay, they would risk getting less than the targeted replacement level of full-time income if the reduced pay level were used in their DB benefit calculations. To meet the challenge of lower DB pension accruals during the phased retirement period, the employer told us they pay workers in the program a full-time salary and allow them to purchase one day of vacation per week for 20 percent of their salary. Thus, phasing workers effectively receive 80 percent of their full-time salary for working four days per week, and a full-time equivalent salary is used for purposes of the DB pension calculation. Source: GAO interview with employer who has a formal phased retirement program. | GAO-17-536
Reported Benefits of Phased Retirement Programs
Defined benefit plan approaches: One employer we spoke with said they overcame the challenge of DB benefit formulas by making changes to the calculation for phased retirement participants. Specifically, the employer said they changed the way that benefits are accrued so there is only a slight difference from the benefits a worker would have received if they continued to work full-time (see sidebar). Another employer reported avoiding any challenges to DB plans because the company had frozen its DB plan prior to introducing phased retirement. Current trends show a significant shift away from DB plans and toward DC plans, so there may be less of a need in the future for approaches to overcome DB plan challenges regarding phased retirement.

Administrative and manager concern approaches: Employers we interviewed said they overcame the challenges of managers' concerns about working with a phased retirement program in ways that worked for each individual organization. The human resources department at one employer responded to the managers who objected to the phased retirement program by promoting the program's benefits. That employer said, for example, that managers would be reminded that having an experienced part-time person was better than having no one, which could be the case if the phased retiree had stopped working altogether. Additionally, managers were reminded that a part-time experienced worker could help train a new person for the job.

Employers also reported making various program adjustments to help with managers' concerns. According to one employer, work needed to be completed even if some workers reduced their hours, so they set up a "flex team." This group of workers is available to fill in as needed throughout the company, and managers can tap it to fill shifts of phased retirement participants. Another approach taken by one employer we interviewed is that when a request for phased retirement is made, they look at the current staff roster to see if there is a part-time worker who might want to work more hours or go full time to fill the gap left by the phased retiree. They noted that because of the nature of their work, they can set up different combinations of hours and shifts.

Employers we interviewed identified four primary, employer-focused benefits of phased retirement: 1) the retention of knowledgeable, highly skilled workers; 2) the transfer of knowledge to younger workers; 3 ) the ability to transition older workers into retirement; and 4) the opportunity for workforce planning. 
Worker retention: Seven of the nine employers we interviewed suggested that allowing knowledgeable, experienced workers to phase into retirement often means they will stay longer with their employer. One employer said they are very satisfied with the phased retirement program because it helps retain highly educated, specialized workers. Another commented that their workforce is very valuable and if these employees were not participating in phased retirement they would be retired.

Knowledge transfer: Seven of the nine employers we interviewed said that maintaining the company knowledge base is critical to employers. One small employer told us their main challenge is the aging of the workforce and succession. We were told by another employer that it is expected a phasing worker will train and mentor his or her replacement, thus maintaining the company knowledge base. Yet another employer said that knowledge transfer is a large component of the phased retirement program and it is expected that workers create a transfer plan.

Transition to retirement: Six of the nine employers we interviewed said providing a gradual pathway to retirement allows both employer and worker to adjust. The culture of the company, one employer said, facilitates the phased retirement program. Another employer noted that phased retirement eases the transition for workers afraid of losing their sense of professional belonging as they transition out of paid work. In this same vein, an employer said that their program provides an attractive off ramp, and added that it is a way to reward a worker for their years of service. Another commented that phased retirement is a positive way for those at or near retirement age to transition softly into retirement-they are participating, but at a reduced pace. Two companies conducted surveys of phased retirement program participants and found that these workers appreciated the ability to transition into retirement.

Workforce planning: Five of the nine employers we interviewed said knowing when workers will retire allows employers to plan for the future. Providing a phased retirement program, one employer told us, makes them aware of workers' retirement plans and thus able to plan for future workforce needs. Another employer said that a major goal is to help the company with workforce planning by encouraging workers to let the company know about their retirement plans and to help transfer their knowledge before they retire. 


\section{Agency Comments}

We provided a draft of the report to the Departments of Labor and the Treasury, the Equal Employment Opportunity Commission, the Internal Revenue Service, the Office of Personnel Management, and the Social Security Administration. The Departments of Labor and the Treasury, the Equal Employment Opportunity Commission, the Internal Revenue Service, and the Office of Personnel Management provided technical comments, which we incorporated as appropriate. The Department of the Treasury and the Internal Revenue Service reviewed this report solely for technical accuracy. They noted that in conducting this review they made no determination on whether the current phased retirement programs described in this report (including in Appendix II) satisfy the requirements of the Internal Revenue Code. The Social Security Administration did not have comments.

As agreed with your offices, unless you publicly announce the contents of this report earlier, we plan no further distribution until 30 days from the report date. At that time, we will send copies to the appropriate congressional committees, the Secretary of Labor, the Secretary of the Treasury, the Acting Chair of the Equal Employment Opportunity Commission, the Commissioner of the Internal Revenue Service, the Acting Director of the Office of Personnel Management, the Acting Commissioner of Social Security, and other interested parties. This report will be available at no charge on the GAO website at http://www.gao.gov.

If you or your staff have any questions about this report, please contact me at (202) 512-7215 or jeszeckc@gao.gov. Contact points for our Offices of Congressional Relations and Public Affairs may be found on the last page of this report. GAO staff who made key contributions to this report are listed in appendix III.

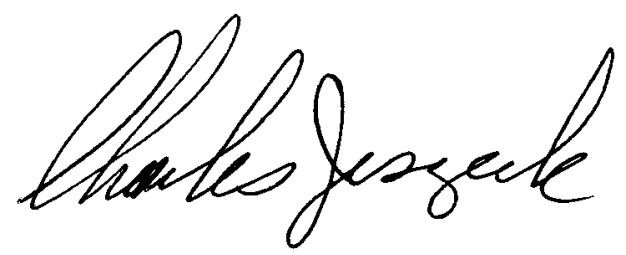

Charles A. Jeszeck

Director, Education, Workforce, and Income Security Issues 


\section{Appendix I: Objectives, Scope, and Methodology}

This report examines (1) the recent trends in the labor force participation of older workers, (2) the extent to which employers have adopted phased retirement programs and what type of employers offer them, and (3) what challenges and benefits, if any, exist to the design and operation of phased retirement programs.

To describe the recent trends in labor force participation of older workers, we analyzed nationally representative data from the Current Population Survey (CPS) and the Health and Retirement Study (HRS), two datasets with information about the labor force participation of older workers.

We analyzed data from the 2005-2016 CPS Annual Social and Economic (ASEC) Supplement, which included the most recent available data. For example, we used CPS ASEC to estimate the labor force participation of older men and women of different age groups, as well as the occupational sector in which older workers work.

CPS is sponsored jointly by the U.S. Census Bureau and the U.S. Bureau of Labor Statistics. ASEC is an annual supplement to the CPS that includes information about family characteristics, household composition, education attainment, previous year's income, work experiences, and other things. It is representative of the U.S. noninstitutionalized population living in households. ${ }^{1}$ We chose CPS because it is the primary source of labor force statistics for the population of the United States, and because it has a large sample size (about 94,000 households in 2016).

Approximately 185,000 total individuals comprised the sample in 2016. Moreover, it included questions relevant to our purposes, such as age, labor force participation, and occupation.

We also analyzed data from the 2004-2014 HRS for the Early Baby Boomer Cohort (born 1948-1953), which included the most recent available data. ${ }^{2}$ For example, we used HRS to estimate the percentage of older workers that can reduce their work hours, that plan to reduce

\footnotetext{
${ }^{1}$ In addition to the civilian population, it is also representative of members of the Armed Forces living in civilian housing units on a military base or in a household not on a military base.

2 This group would have been ages 51 to 56 in 2004, the first year they were included in the survey, and ages 61 to 66 in 2014, the last year for which we have complete data. This cohort began transitioning to retirement from 2004-2014, going from an estimated10 percent of respondents indicating they were retired or partly-retired in 2004 , to an estimated 53 percent indicating they were retired or partly-retired by 2014 .
} 
their work hours as they transition to retirement, that would like to reduce hours even if their pay is also reduced, and the percentage that are partly retired. We also used HRS to analyze other information for this cohort, such as the percentage that said their pension or health benefits would be affected by reducing their hours and the percentage that retired sooner than expected.

The University of Michigan's HRS is a longitudinal panel study that surveys a representative sample of approximately 20,000 Americans over the age of 50 every 2 years, with new cohorts being added to the sample every 6 years. We chose HRS because of its large sample size, focus on older Americans, and because it included questions relevant to our purposes. For example, it asks about workers' plans for retirement and work patterns. Moreover, the longitudinal panel structure allowed us to examine changes over time, such as an individual's plans at one period compared to the outcomes in another period.

We examined the reliability of the CPS and HRS by reviewing documentation and conducting selected data checks. For example, we reviewed codebooks, technical documentation, and information about survey weights for each dataset. We also conducted electronic testing to check for missing data or errors. We found the data we used to be sufficiently reliable for our purposes.

Nonetheless, as with all survey data, estimates from the CPS and HRS are subject to some sampling error since the samples are one of a large number of random samples that might have been drawn. Since each possible sample could have provided different estimates, we express our confidence in the precision of the sample results as 95 percent confidence intervals. These intervals would contain the actual population values for 95 percent of the samples that could have been drawn. In this report, we report percentage or other numerical estimates along with their 95 percent confidence intervals. Unless otherwise noted, all percentage estimates based on the CPS have 95 percent confidence intervals that are within about $+/-2$ percentage points or less, and all percentage estimates based on the HRS have 95 percent confidence intervals that are within $+/-3$ percentage points.

The survey literature refers to both the CPS and HRS samples as complex designs, a loosely-used term meant to denote the fact that the sample incorporates special design features such as stratification, clustering and differential selection probabilities (i.e., weighting) that analysts must consider in computing sampling errors for sample 
estimates of descriptive statistics and model parameters. For CPS, we used weights provided by the U.S. Census Bureau. For HRS, we adapted the Balanced Repeated Replication (BRR) method to develop and use weights specific to the Early Baby Boomer cohort. The BRR method is applicable to stratified sample designs with two half-sample units (i.e., primary sampling units) selected from each stratum. When full balancing of the half-sample assignments is employed, BRR is the most computationally efficient of the replicated variance estimation techniques. $^{3}$

To inform all sections of this report, we reviewed relevant federal laws and regulations and conducted a literature review regarding the prevalence of phased retirement programs in the United States. The literature review included scholarly journals, conference and working papers, and trade news published between 2006 and 2016. The trade news helped us also identify industry surveys and reports. We excluded publications limited to a particular industry, those not based on a reputable data source, and those whose authors are affiliated with a partisan organization. From this search, we identified 20 publications (11 quantitative studies for which we reviewed the methodology and 9 qualitative articles that we used to describe the perspectives or observations of the experts who authored them). All 11 studies described the prevalence of phased retirement (4 described percentage of workers who gradually retire, and 7 described the percentage and/or type of employers who offer phased retirement). Eleven of the publications (2 quantitative and all 9 qualitative) described challenges to phased retirement.

While we concluded that each of the publications we included was appropriate for our purposes, they did have some limitations. For example, the quantitative studies were based on surveys that had various sample sizes, populations, and were from various years. ${ }^{4}$ Moreover, none was nationally representative of all employers and there were varying definitions of phased retirement, though each quantitative study described phased retirement with the same employer. ${ }^{5}$ For our purposes, we distinguished the studies that described formal phased retirement (an

\footnotetext{
${ }^{3}$ K.M. Wolter, Introduction to Variance Estimation, New York: Springer-Verlag (1985).

${ }^{4}$ As appropriate, we noted these differences in the text of the report.

5 In contrast, the studies did not focus on situations in which the worker "gradually retires" by working for another employer.
} 
employer-based program in which workers reduce their working hours in order to transition into retirement) from those that described informal phased retirement (such as an ad hoc agreement or situation in which a worker retires and is rehired on a part-time basis, such as a contractor). Nonetheless, these publications provide valuable information on the prevalence of phased retirement and the challenges to such programs.

To understand the prevalence of phased retirement programs and any issues designing and operating these programs, we spoke with agency officials, including officials from the Department of Labor. For example, we discussed the ERISA Advisory Council reports with officials from the Department of Labor's Employee Benefits Security Administration, the Department of the Treasury, and the Internal Revenue Service.

We also interviewed 16 experts on the topic of phased retirement. We identified these experts through our review of relevant literature and through expert referral. The experts represent a variety of fields, such as consulting, industry groups, interest groups, and academics, and we evaluated these experts' independence, for example, by confirming they had no known source of bias and were not affiliated with a partisan organization.

Lastly, we conducted semi-structured interviews with 9 employers that offer or considered offering phased retirement programs (see appendix II for more information). Six employers had formal phased retirement programs, and 3 did not. Of the 3 without formal phased retirement programs, 2 had phased retirement programs that were not written down or formalized but that otherwise met our definition of a phased retirement program, ${ }^{6}$ and 1 employer considered but did not implement phased retirement. We identified these employers using publicly available websites, relevant literature, and expert recommendations. We also considered proximity to other employers and GAO offices. While the information from these interviews is not generalizable, it provided rich examples and perspectives on the issues related to phased retirement.

We selected these 9 employers to represent a variety of employer types by location, size, industry, and retirement plan. We spoke with 4 employers in the Midwest, 4 employers in the West, and 1 employer in the South. We spoke with 2 employers with fewer than 200 employees, 2

\footnotetext{
${ }^{6}$ Both of these employers made phased retirement available to all workers.
} 
with 200 up to 2,500 employees, and 5 with over 2,500 employees. We spoke with employers in various industries, including consulting, higher education, finance, and health care. Five employers had only a defined contribution plan, 3 had both a defined contribution and defined benefit plan, and one had a deferred compensation plan. 


\section{Appendix II: Profiles of Phased Retirement Programs for Selected Employers}

Formal phased retirement is an employer-based program in which older workers can reduce their working hours in order to transition into retirement. We conducted semi-structured interviews with 9 employers that offered or considered offering phased retirement programs. Six employers had formal phased retirement programs, and three did not. Of the 3 without formal phased retirement programs, 2 had phased retirement programs that were not written down or formalized but that otherwise met our definition of a phased retirement program, and 1 had considered but did not implement a phased retirement program. We identified these employers using publicly available websites, relevant literature, and expert recommendations. The employers represent a variety of employer types by location, size, industry, and retirement plan. Below are profiles of the 8 employers with whom we conducted interviews who offered formal or informal phased retirement. The following information reflects how each employer generally responded to the questions we asked during the semi-structured interviews. We did not independently verify the information each employer provided to us about their phased retirement program.

\section{Employer 1:}

- Features of phased retirement:

- Basics: In this formal phased retirement program, workers work 80 percent time and receive 80 percent of pay and 80 percent of their bonus money, but the defined benefit (DB) pension formula is based on full salary for up to five years because workers appear full time on paper. ${ }^{1}$

- Cited benefits/advantages: Retention of workers and development of future leaders and the ability of the employer to do workforce planning. The employer has conducted surveys of workers and managers, and feedback about the phased retirement program is very positive.

- Eligible workers: All employees in the United States who are at least age 55 with 10 or more years of service, who have achieved or exceeded performance expectations, and who have permission from management are eligible.

- Hours reduction allowed: 20 percent

\footnotetext{
${ }^{1}$ Workers also have the option to take additional leave instead of working a regular parttime schedule.
} 
- Length of phased retirement: Workers can stay in the program for any length of time as long as they are meeting program standards and have their manager's approval.

- Knowledge transfer: Phasing workers agree to spend time transferring knowledge, skills, and expertise. For each year the worker participates, he or she creates a proposal that includes a knowledge transfer plan with recommendations on how it will ensure business continuity.

- Effect on health care benefits: Participation in phased retirement does not affect the cost of health insurance for the worker or employer.

- Effect on pension benefits:

- DB plan: For phased retirement participants, DB benefits are based on the worker's full-time salary and reduced bonus. This mitigates the effect of reduced pay on the worker's benefit. However, if the worker participates in the program for more than five years, the pension will be affected.

- DC plan: The defined contribution (DC) plan contribution is based on a worker's full-time salary and reduced bonus.

\section{Employer 2:}

- Features of phased retirement:

- Basics: In this formal phased retirement program, workers and managers develop a structured plan to transfer knowledge and transition to retirement within two years.

- Cited benefits/advantages: The primary benefit is knowledge and skills retention. Additionally, it helps the company with workforce planning by encouraging workers to inform the company about their retirement plans and to help transfer their knowledge before they retire. The employer has conducted surveys of workers and managers, and feedback about the phased retirement program is very positive.

- Eligible workers: All workers who have reached age 60 and who have been at the company for five or more years and who have permission from their managers and human resources, are eligible.

- Hours reduction allowed: Participants must work at least 50 percent and no more than 80 percent. A participant may submit a 
request to work less than 50 percent, though they lose eligibility for health care benefits.

- Length of phased retirement: Phasing can last from six months up to two years.

- Knowledge transfer: Knowledge transfer is a large component of the program. The employer provides many tools and guidelines, and it is expected that phasing workers create a transfer plan.

- Effect on health care benefits: The employer provides a subsidy so that the health insurance rates for phased retirement participants are the same as if they were working full time.

- Effect on pension benefits: There is no DB plan. The DC plan contribution formula does not change with phased retirement, but the amount of pay upon which the contribution is based changes in proportion to the worker's reduced salary.

- Other: To deal with the challenge of completing work with phasing workers working only part time, the company has a group of workers who fill in as needed throughout the company. Members can be called on to fill in for phasing workers.

\section{Employer 3:}

- Features of phased retirement:

- Basics: In this formal phased retirement program, workers in units that have implemented the program may participate.

- Cited benefits/advantages: The benefits are primarily worker retention and knowledge transfer, training, and mentoring of staff that remain.

- Eligible workers: Eligibility is up to management and management's perception of the business need to retain staff, and of the ability to fill a position with a part-time worker. It can begin at any age. Some work units have implemented the program, while others have not.

- Hours reduction allowed: Participants typically work 60 percent of full time.

- Length of phased retirement: (no response)

- Knowledge transfer: There is an expectation that participants will mentor or train staff, but there is no formal knowledge transfer program. 
- Effect on health care benefits: If the worker is more than 60 percent time, the employer provides a subsidy so that the health insurance rates for phased retirement participants are the same as if they were working full time. However, employer-provided health benefits end at age 65-the age at which workers become eligible for Medicare.

- Effect on pension benefits: There is no DB plan. The employer provides a dollar-to-dollar match for the DC plan. Since it is not based on a proportion of the worker's salary, the match remains unchanged regardless of participation in phased retirement.

\section{Employer 4:}

\section{- Features of phased retirement:}

- Basics: In this formal phased retirement program, workers are allowed flexibility within the program's basic rules. Workers can retire fully at any point during phased retirement.

- Cited benefits/advantages: Phased retirement helps avoid a retirement "cliff." Instead, it is a ramp from 100 percent time to 0 percent time. Additionally, phased retirement allows the employer to hire new workers at a lower cost.

- Eligible workers: Must be at least age 55 and an eligible worker for at least seven years.

- Hours reduction allowed: The phasing worker and his or her supervisor negotiate the workload.

- Length of phased retirement: Phasing may last one to five years.

- Knowledge transfer: Knowledge transfer and mentoring is done on a case-by-case basis.

- Effect on health care benefits: The employer provides a subsidy so that the health insurance rates for phased retirement participants are the same as if they were working full time.

- Effect on pension benefits: There is no DB plan. The DC plan contribution formula does not change with phased retirement, but the amount of pay upon which the contribution is based changes in proportion to the worker's reduced salary. 


\section{Employer 5:}

\section{- Features of phased retirement:}

- Basics: In this formal phased retirement program, a workers' unit must determine that participation can be accommodated given staffing levels in that unit.

- Cited benefits/advantages: Phased retirement helps the employer retain specialized or knowledgeable workers and uses these workers to bridge the gap between experienced and inexperienced workers. It also helps with workforce planning.

- Eligible workers: All who meet basic requirements of at least age 55 , worked at least 10 years with the employer, have worked a certain number of hours in one of the three prior calendar years and per pay period are eligible to apply. Each request is approved or rejected on a case-by-case basis. The supervisor and a human resources representative discuss the request with the employee. A primary consideration is whether phased retirement for this worker can be accommodated given staffing levels in the worker's unit.

- Hours reduction allowed: While there is no requirement, the average phased retirement participant works 24 hours a week.

- Length of phased retirement: There is no restriction on the length of phasing.

- Knowledge transfer: Phasing workers may be tapped to pass on knowledge both formally and informally to younger workers.

- Effect on health care benefits: Participants who have worked 10 years with the employer pay health insurance costs at the parttime worker rate. For those who have worked 20 years, the employer provides a subsidy so that the health insurance rates for phased retirement participants are the same as if they were working full time.

- Effect on pension benefits: There is no DB plan. For the DC plan, the contribution formula does not change with phased retirement, but the amount of pay upon which the contribution is based changes in proportion to the worker's reduced salary. 


\section{Employer 6:}

\section{- Features of phased retirement:}

- Basics: In this formal phased retirement program, workers must transition into full retirement within three years.

- Cited benefits/advantages: This program provides participants the ability to adjust to full retirement by reducing their workloads gradually, while they are still contributing to their units.

- Eligible workers: Certain full-time workers who are at least age 57 and have completed at least 10 years of service are eligible.

- Hours reduction allowed: Participants may work 75 percent or 50 percent time.

- Length of phased retirement: Phased retirement can last no longer than three years.

- Knowledge transfer: There is no knowledge transfer requirement.

- Effect on health care benefits: Participation in phased retirement does not affect the cost of health insurance for the worker or employer.

- Effect on pension benefits: Eligible workers have a choice between coverage by a DB plan or a DC plan.

- DB plan: Phased retirement affects the final years' contributions to the DB plan because workers have a lower salary while participating in phased retirement. However, this does not necessarily have an effect on the amount of the DB pension benefit at full retirement because the current calculation is based on the worker's highest years of earnings, not the most recent.

- DC plan: For the DC plan, the contribution formula does not change with phased retirement, but the amount of pay upon which the contribution is based changes in proportion to the worker's reduced salary. 


\section{Employer 7:}

\section{- Features of phased retirement:}

- Basics: This phased retirement program is not formalized but otherwise meets our definition of a phased retirement program. While there is no formal structure, the program can be set up in a number of ways. A worker can switch out of duties that are on his or her career track, to less stressful duties, or less complex duties; or a worker could phase to part-time at their regular duties.

- Cited benefits/advantages: The organization is able to retain people who do highly specialized work. It helps with the transition as a worker near retirement works with his or her replacement.

- Eligible workers: All workers are eligible and phased retirement can begin at any age.

- Hours reduction allowed: There is no requirement.

- Length of phased retirement: There is no limit to how long a worker can phase.

- Knowledge transfer: There is no official policy but the program helps with the transition from one worker to the next as the phasing retiree works with his or her replacement.

- Effect on health care benefits: If a phasing retiree works at least 25 hours per week, it does not affect the cost of health insurance for the worker or employer.

- Effect on pension benefits: There is no DB plan. The DC plan contribution formula does not change with phased retirement, but the amount of pay upon which the contribution is based changes in proportion to the worker's reduced salary.

\section{Employer 8:}

- Features of phased retirement:

- Basics: This phased retirement program is not formalized but otherwise meets our definition of a phased retirement program. In consultation with management, workers may develop a plan to reduce their hours prior to full retirement and train their replacement.

- Cited benefits/advantages: The ability to offer phased retirement helps the company attract and retain its highly skilled workforce. 
- Eligible workers: It is available to all employees. Employees can begin phasing at any age.

- Hours reduction allowed: While there is no requirement, the most common reduction in hours is to 50 to 60 percent time.

- Length of phased retirement: While there is no requirement, workers generally phase for one to two years.

- Knowledge transfer: It is expected that an employee will train and mentor his or her replacement.

- Effect on health care benefits: If the employee works 20 or more hours per week, the employer provides a subsidy so that the health insurance rates for phased retirement participants are the same as if they were working full time.

- Effect on pension benefits: There is no DB plan and no DC plan. The employer funds a deferred compensation plan, and the contribution formula does not change with phased retirement, but the amount of pay upon which the contribution is based changes in proportion to the worker's reduced salary. 


\section{Appendix III: GAO Contact and Staff Acknowledgments}

GAO Contact

Charles A. Jeszeck, (202) 512-7215 or jeszeckc@gao.gov

Staff

Acknowledgments
In addition to the contact named above, Michael Collins (Assistant Director), Laura Hoffrey (Analyst-in-Charge), Laurel Beedon, Samuel Kelly-Quattrocchi, and Jessica Rider made key contributions to this report. Also contributing to this report were Carol Bray, Lawrance Evans Jr., Sarah Gilliland, Robert Goldenkoff, Kirsten Lauber, Sheila McCoy, Erin McLaughlin, Mimi Nguyen, Jessica Orr, Dae Park, Rhiannon Patterson, Oliver Richard, Matthew Saradjian, Joseph Silvestri, Adam Wendel, and Daphne Williams. 


\section{Related GAO Products}

401(k) Plans: Effects of Eligibility and Vesting Policies on Workers' Retirement Savings. GAO-17-69. Washington, D.C.: October 21, 2016.

Social Security's Future: Answers to Key Questions. GAO-16-75SP. Washington, D.C.: October 2015.

Retirement Security: Federal Action Could Help State Efforts to Expand Private Sector Coverage. GAO-15-556. Washington, D.C.: September 10, 2015.

401(k) Plans: Clearer Regulations Could Help Plan Sponsors Choose Investments for Participants. GAO-15-578. Washington, D.C.: August 25, 2015.

Retirement Security: Most Households Approaching Retirement Have Low Savings. GAO-15-419. Washington, D.C.: May 12, 2015.

Retirement Security: Women Still Face Challenges. GAO-12-699. Washington, D.C.: July 19, 2012.

Unemployed Older Workers: Many Experience Challenges Regaining Employment and Face Reduced Retirement Security. GAO-12-445. Washington, D.C.: April 25, 2012.

Income Security: Older Adults and the 2007-2009 Recession. GAO-12-76. Washington, D.C.: October 17, 2011.

Highlights of a GAO Forum: Engaging and Retaining Older Workers. GAO-07-438SP. Washington, D.C.: February 2007.

Retirement Decisions: Federal Policies Offer Mixed Signals about When to Retire. GAO-07-753. Washington, DC: July 11, 2007.

Older Workers: Labor Can Help Employers and Employees Plan Better for the Future. GAO-06-80. Washington, D.C.: December 5, 2005.

Older Workers: Demographic Trends Pose Challenges for Employers and Workers. GAO-02-85. Washington, D.C.: November 16, 2001. 
The Government Accountability Office, the audit, evaluation, and investigative arm of Congress, exists to support Congress in meeting its constitutional responsibilities and to help improve the performance and accountability of the federal government for the American people. GAO examines the use of public funds; evaluates federal programs and policies; and provides analyses, recommendations, and other assistance to help Congress make informed oversight, policy, and funding decisions. GAO's commitment to good government is reflected in its core values of accountability, integrity, and reliability.

\section{Obtaining Copies of GAO Reports and} Testimony
The fastest and easiest way to obtain copies of GAO documents at no cost is through GAO's website (http://www.gao.gov). Each weekday afternoon, GAO posts on its website newly released reports, testimony, and correspondence. To have GAO e-mail you a list of newly posted products, go to http://www.gao.gov and select "E-mail Updates."

\section{Order by Phone}

The price of each GAO publication reflects GAO's actual cost of production and distribution and depends on the number of pages in the publication and whether the publication is printed in color or black and white. Pricing and ordering information is posted on GAO's website, http://www.gao.gov/ordering.htm.

Place orders by calling (202) 512-6000, toll free (866) 801-7077, or TDD (202) 512-2537.

Orders may be paid for using American Express, Discover Card, MasterCard, Visa, check, or money order. Call for additional information. Visit GAO on the web at www.gao.gov and read The Watchblog.

To Report Fraud, Waste, and Abuse in Federal Programs

\section{Contact:}

Website: http://www.gao.gov/fraudnet/fraudnet.htm

E-mail: fraudnet@gao.gov

Automated answering system: (800) 424-5454 or (202) 512-7470
Congressional Relations
Katherine Siggerud, Managing Director, siggerudk@gao.gov, (202) 512-4400, U.S. Government Accountability Office, 441 G Street NW, Room 7125, Washington, DC 20548

\section{Public Affairs}

Chuck Young, Managing Director, youngc1@gao.gov, (202) 512-4800

U.S. Government Accountability Office, $441 \mathrm{G}$ Street NW, Room 7149 Washington, DC 20548

\section{Strategic Planning and External Liaison}

James-Christian Blockwood, Managing Director, spel@gao.gov, (202) 512-4707 U.S. Government Accountability Office, 441 G Street NW, Room 7814, Washington, DC 20548

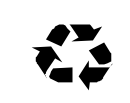

Please Print on Recycled Paper. 